\title{
Ultrastructure and Functional Morphology of the Appendages in the Reef-Building Sedentary Polychaete Sabellaria Alveolata (Annelida, Sedentaria, Sabellida)
}

Christian Meyer

Universty of Osnabrueck

Thomas André

University of Osnabrueck

Günter Purschke ( $\nabla$ gpurschk@uni-osnabrueck.de )

University of Osnabrueck https://orcid.org/0000-0002-2572-3390

\section{Research}

Keywords: tentacular filaments, palps, opercular papillae, branchiae, blood vessels, coelom, operculum, receptor cells, cartilage tissue, ciliated epithelia

Posted Date: August 20th, 2020

DOI: https://doi.org/10.21203/rs.3.rs-60217/v1

License: (c) (1) This work is licensed under a Creative Commons Attribution 4.0 International License.

Read Full License

Version of Record: A version of this preprint was published at BMC Zoology on March 9th, 2021. See the published version at https://doi.org/10.1186/s40850-021-00068-8. 


\section{Abstract}

Background: The sedentary polychaete Sabellaria alveolata, the sandcastle or honeycomb worm, possesses four different kinds of appendages besides the parapodia: opercular papillae, tentacular filaments, palps, and branchiae. It exhibits a highly specialized anterior end, the operculum, formed by the prostomium, peristomium, and two anterior segments. Besides the median organ, the operculum comprises opercular papillae, tentacular filaments, and palps. Paired branchiae are present from the second thoracic chaetiger onwards on the posteriorly following segments except for the last ones. Only the palps have been studied thus far by transmission electron microscopy in late larvae of a different species. In order to bridge the data gap, we investigated the appendages of $S$. alveolata by applying light microscopy, confocal laser scanning microscopy, scanning, and transmission electron microscopy.

Results: In S. alveolata the entire body is covered by a thin cuticle characterized by the absence of layers of parallel collagen fibers with no differentiation between the various body regions including the branchiae. The opercular papillae bear numerous tufts of receptor cells and lack motile cilia. The tentacular filaments show a distinctive ciliation pattern; their most conspicuous morphological feature is their cell-free cartilaginous endoskeletal structure enclosed by ECM. Besides musculature the filaments include a single coelomic cavity but blood vessels are absent. The palps are ciliated with two coelomic cavities and a single blind-ending blood vessel. Besides external ciliation and receptor cells, the coelomate branchiae are highly vascularized and equipped with numerous blood spaces extending deep into the basal regions of the epidermal cells (diffusion distances: 150-400nm).

Conclusions: All appendages, including the branchiae, bear receptor cells and, as such, are sensory. The opercular papillae resemble typical parapodial cirri. In contrast, the tentacular filaments have a double function: sensing, collecting and transporting particles. A similarity to branchiae can be excluded. The palps are typical grooved palps similar to another sabellariid studied. A revised classification of polychaete branchiae is suggested; thereby, the branchiae of $S$. alveolata belong to the most common type comprising coelom, musculature, and blood vessels. The results indicate that diffusion distances between blood and environment have been underestimated in many cases.

\section{Background}

Sabellariidae Johnston, 1865 is a highly specialized group of sedentary annelids living in tubes built of cemented sand grains [1-3]. Although the group only comprises approximately 130 species, they are well known because of the gregarious behavior of certain species that may form large reefs. Due to the characteristic shape of their tube openings, they are also known as sandcastle or honeycomb worms. The animals exhibit heteronomous segmentation, and their highly modified anterior end forms the operculum representing a multifunctional structure [3-5]. Their body may be subdivided into operculum, thorax, parathorax, abdomen and caudal region $[2-4,6]$. Sometimes the thorax is included in the operculum proper. Besides the parapodia, the animals bear four different kinds of appendages, opercular papillae, 
tentacular filaments, palps, and branchiae. Whereas the former three are related to the anterior end, the branchiae are present for multiple segments beginning with the second thoracic segment [3].

The operculum is the most characteristic feature of sabellariids and represents the head region, which seals the tube when the animals withdraw, protecting them against unfavorable conditions such as predation, desiccation, and deposition of particles [1-3]. The operculum is unique in Sabellariidae, is seen as their fundamental apomorphy [3] and is regarded to be their most important protective and sensory structure $[2,4,5,7,8]$. The operculum comprises two lobes, and anteriorly bears one to three rows of strong protective chaetae, the paleae, immediately followed by a row of opercular papillae $[2,4]$. Laterally on the lobes, usually, numerous oral or tentacular filaments arise, and a pair of palps completes the anterior appendages. At the dorsal junction of the opercular lobes, a crest is located running from the upper lip towards the opercular crown, called the median ridge, which anteriorly may hold the median organ in certain species [5]. The median organ (as the dorsal hump in larvae) is considered to play a significant sensory role during settlement, metamorphosis, and in adults $[5,6,9]$. This part of the operculum bears eyes in addition to the cerebral eyes in many species $[2,5,9]$. Very likely, these eyes are essential for the escape or shadow reflex when the animals withdraw into their tubes [6].

Although the external morphology of the group is well known, to date, Sabellariidae have seldom been studied by transmission electron microscopy (TEM). These previous investigations include general observations on larvae and metamorphosis $[10,11]$, oogenesis and spermatogenesis $[12,13]$ as well as some more preliminary data on the tentacular filaments [14]. Among their sensory structures, only the palps (termed tentacles) have been studied thus far in late larvae of Phragmatopoma californica [15, 16]. Recent investigations on the sensory organs in Sabellaraiidae focused on the thus far underestimated importance of the median organ, neglecting, however, the possible sensory role of the other appendages $[2,5,6,9]$.

In Sabellariidae, data on the branchiae are only available on the light microscopic level [17-19]. However, ultrastructural observations exist for several polychaete species [20-21]. These reveal a certain degree of variability among the taxa investigated besides certain common features such as external ciliation, a comparatively thin cuticle, and epithelia, blood vessels, and coelomic spaces. In addition to the obvious function of oxygen uptake, involvement in osmoregulation and ion exchange has been proposed in Diopatra neapolitana [23], and ammonia excretion has been demonstrated in Eurythoe complanata [24]. These data highlighted certain inconsistencies, raised questions, and prompted attempts to classify these appendages. The different classifications have been criticized by Belova and Zhadan [21], who claimed a need for revision.

Since the ultrastructure and morphology of the different appendages were unknown, an ultrastructural investigation was designed for Sabellaria alveolata, a species common in European waters [5]. In this species, individuals possess all kinds of appendages mentioned. The present study combines light microscopy, scanning, and transmission electron microscopy to describe the structure of these organs. It is supplemented with a few confocal laser scanning microscopy observations using antibodies for 
neuronal markers to obtain information on the innervation of these structures. All appendages represent outgrowths of the body wall comprising epidermis and mesodermal tissues; blood vessels and coelomic spaces were only found in the palps and branchiae. They bear numerous receptor cells and, as such, are also sensory appendages. Except for the opercular papillae, the appendages are equipped with a specific pattern of densely arranged motile cilia. A revised classification of polychaete branchiae is suggested; the branchiae of $S$. alveolata belong to the most common type comprising coelom and blood vessels. The ultrastructure of the opercular papillae and branchiae are described here for the first time in Sabellariidae. Data on the tentacular filaments can be complemented and substituted, whereas the palps show a similar fine structure as in Phragmatopoma californica studied previously $[15,16]$.

\section{Results}

\section{Position of appendages}

The body of the reef-building polychaete $S$. alveolata shows an organization typical of Sabellariidae. In brief, five distinct body regions can be determined from anterior to posterior: opercular, thoracic, parathoracic, abdominal, and caudal region (Fig. 1). Except for the caudal region, each of these exhibits multiple specialized appendages.

The opercular region on the anterior end bears three different kinds of appendages. Most anteriorly, it carries a ring of opercular papillae present directly underneath the opercular paleae. Each papilla is a short, finger-like outgrowth of the anterior body wall and does not surpass the roundish disc of opercular paleae when viewed anteriorly (Figs. 1, 2A). In addition, numerous tentacular filaments insert on the ventral side of the opercular lobes, and the latter fuse on the dorsal side. Several parallel rows of contractile tentacle filaments are present on each lobe, while each row consists of numerous heavily ciliated tentacle filaments (Figs. 1, 3A). Inside the opercular cavity, formed by the dorsal partially fused opercular lobes, two palps are located and protrude anteriorly (Fig. 1, inset).

Besides the parapodia, branchiae occur in the following thoracic, parathoracic, and abdominal regions. These are paired, ciliated structures present on the dorsal side from the second thoracic chaetiger onward and the posteriorly following segments, diminishing in size continuously (Figs. 1, 7A, 8A-C). The branchiae are finger-like outgrowths of the body wall emerging just above the notopodia and are absent in the more posterior segments. The number of abdominal segments depended on the size of the animals and was between 24 and 34 in the specimens investigated, as was the number of branchiae. Approximately 10 abdominal segments were devoid of branchiae in the specimens investigated.

\section{Opercular papillae}

The opercular papillae of $S$. alveolata are located circularly around the anterior operculum, underneath the opercular paleae (Figs. 1, 2A). Each papilla is a single finger-like outgrowth, becoming thinner distally and roundish on the tip, presenting several groups of cilia (Fig. 2B). From their base to the tip, they measured 
approximately $120-130 \mu \mathrm{m}$, and the diameter of the structure was approximately $50-60 \mu \mathrm{m}$ at the base. The number of opercular papillae per individual was not easy to determine, but in our material comprising not only adult individuals, we counted between 12 and 20 pairs of papillae. Each papilla consists of epidermis and a central cylinder of connective tissue (Fig. 2D).

The inner, central part of each opercular papilla consists of a 17-23 $\mu \mathrm{m}$ thick cylindrical connective tissue layer, apically separated via a distinctly separated extracellular matrix (ECM) from the outer approximately $15 \mu \mathrm{m}$-thick epidermal epithelium. The connective tissue of each papilla is a direct result of the connective tissue inside the operculum (Fig. 2D). The connective tissue consists of a loose and irregular network of fine fibrillar material and houses numerous cell bodies of mesodermal cells and muscle fibers. The myofilaments primarily follow the longitudinal axis of the papillae. In the muscle cells, nuclei and mitochondria are located towards the inner side, whereas the myofilaments are close to the ECM. Blood vessels are absent in the papillae (Fig. 2D, E).

The epidermis consists of only a few cell types comprising supportive cells, gland cells, and sensory cells (Fig. 2D). All cells are interconnected by typical junctional complexes comprising a zonula adherens followed by a septate junction (Fig. 2C, G, H). It is covered by an approximately $1 \mu$ m-thick cuticle penetrated by numerous microvilli and lacking collagen fibers. The cuticle is composed of scarce fine fibrils which become denser apically, and collagen fibers are absent. It is covered by a thin, sheet-like epicuticle (Fig. 2D, H). The microvilli branch, and surpass the cuticle proper for approximately $100 \mathrm{~nm}$ and form an apical layer of densely arranged microvillar tips (Fig. 2G, H). The supportive cells are more or less columnar and are characterized by a prominent basal-apical system of intermediate filaments (Fig. 2E) connecting the ECM with hemidesmosomes located at the bases of the microvilli. A few gland cells are interposed between the supportive cells (Fig. 2C, D). They possess electron-lucent, heterogenous secretory content. Apically, a circle of microvilli forms an aperture, but the cuticle is not interrupted in these areas (Fig. 2C).

The groups of cilia present on the surface of the papillae and arranged in rows belong to sensory cells without exception; motile cilia are absent on the papillae (Fig. 2G, H). Each group of cilia is formed by several sensory cells, the majority of which are monociliated (Fig. 2G, H). Two types may be distinguished by the different electron-density of their dendritic processes. The cytoplasm in the more frequent type of these cells is more electron-dense and contains basally located nuclei and numerous oval-shaped mitochondria (Fig. 2D, G, H). These cells are monociliated, and although apical microvilli surround each cilium, these do not form a typical collar around the cilia. A strong bundle of intermediate filaments enters each of the branched microvilli. The basal bodies of the cilia extend above the level of the apical cell membrane before giving rise to the axoneme. Basally a small rootlet is attached to the basal bodies (Fig. 2G), and an accessory centriole may also be present (Fig. 2H). The other receptor cell type possesses a more electron-lucent cytoplasm (Fig. 2G, H). These cells bear more than one cilium; their number, however, could not be determined. All receptor cell dendrites contain numerous microtubules following their longitudinal axis.

\section{Tentacular Filaments}


The tentacular or oral filaments of $S$. alveolata insert on the ventral side of the opercular lobes and are arranged in 8-10 rows, each comprising 8-10 filaments (Figs. 1, 3A). A single individual of S. alveolata may possess between 128 and 200 tentacular filaments. On the frontal side, each filament possesses a band of dense cilia running from the base to the tip of the tentacle, laterally flanked by 3 groups of longer cilia (Figs. 3B, D, 5A). The afrontal side of the tentacle is lacking a ciliary band but features some smaller groups of cilia (Figs. 3B, C, 4). Each tentacle is innervated by two nerves running along the longitudinal axis on the afrontal side (Fig. 3E-H). Repeatedly they branch off in a regular pattern, and these processes finally give rise to sensory cilia (Fig. 5G, H). However, some of these proceed towards the lateral groups of longer motile cilia (Fig. 5H).

Each tentacle filament is surrounded by an approximately $1 \mu \mathrm{m}$-thick cuticle penetrated by microvilli. The microvilli break through the cuticle, branch distally into two or more branches, terminate in a knob-like tip, and carry an apical glycocalyx (Fig. 5A). As on the opercular papillae, collagenous fibers are lacking.

The underlying epidermis is thicker on the frontal side than on the afrontal side and is composed of unciliated supportive cells with prominent bundles of intermediate filaments, ciliated supportive cells, and a few gland cells (Fig. 4). The latter have only been found on the frontal ciliated side of the filaments. A characteristic feature of the epidermis is the occurrence of comparatively large intercellular spaces, especially between the unciliated cells on the afrontal side (Fig. 4 asterisks). The frontal ciliary band is mainly formed by these ciliated cells, but a few unciliated cells are interspersed between them (Fig. 4). The three prominent groups of longer cilia, present laterally next to the longitudinal ciliary band, are each composed of a single multiciliated cell, each bearing more than 100 cilia. Each ciliary bundle is between approximately 4-8 $\mu \mathrm{m}$ thick and wide (Fig. 5A). The distance between the following dorsal/anterior ciliary groups is $25-50 \mu \mathrm{m}$. Ultrathin sections through these cells reveal that the density of cilia varies between the cells with longer and shorter cilia being denser in the cells with the long cilia ( 4.25 cilia/ $\mu \mathrm{m}^{2}$ vs. 1 cilium $/ \mu \mathrm{m}^{2}$ ). Smaller groups of ciliated processes of receptor cells are poorly distributed on all sides of the tentacle (Fig. 5B, C), also visible after staining with antibodies against acetylated a-tubulin (Fig. 3E-H); the receptor cells show the same characteristics as on the opercular papillae (Fig. 5B, C). All epithelial cells are interconnected to their neighbors by apical zonulae adherentes and septate junctions (Fig. 5C).

A prominent, u-shaped skeletal structure observed in cross-sections is present within the epidermis of each tentacle, being its most characteristic feature (Fig. 4). Basally these cartilage-like structures are blind-ending and are not interconnected. Extending from the base to the tip, this cartilage-like structure thus forms a trench with its lumen facing the frontal side in each tentacular filament. The cartilage is surrounded by an ECM on all sides, which also connects both upper ends of the trench and thus separates a cylindrical inner tissue layer from the epidermis (Figs. 4, 5D, G). This layer is a direct result of the mesodermal tissue of the body consisting of connective tissue cells, longitudinal oblique, and circular orientated muscle fibers comprising the main musculature of the filaments (Fig. 5D, F). Within this musculature, longitudinal fibers strongly predominate. Frequently a central coelomic space was encountered in this central cylinder of mesodermal tissue (Fig. 5D). Adhering junctions have been 
observed between the muscle fibers surrounding the coelomic cavity (Fig. 5E). Besides the main muscle bundle, a few additional but rather thin longitudinal muscle fibers are distributed outside this central cylinder and occur laterally and on the afrontal side (Fig. 5G). These are entirely enclosed by ECM as well and not epitheliomuscular cells. On the afrontal and lateral sides, the cartilage structure is in contact with extensions of the epidermal supportive cells (Fig. 5B, G). This cartilage-like structure appears homogenous in semithin sections and stains red in toluidine blue staining, whereas in ultrathin sections, it shows a fine fibrillary structure (Fig. 5B, D, G, H). At higher magnification thinner and thicker structures can be distinguished, the larger ones measuring approximately $40 \mathrm{~nm}$ in diameter and the thinner ones, half this size (Fig. $5 \mathrm{H}$ ). In a more or less regular pattern, a smaller number of additional fibers traverse the cartilage structure radially (Fig. 5B, D). Blood vessels were not observed in the tentacular filaments.

\section{Palps}

In the resting position, the two palps of adult $S$. alveolata lie inside the opercular cavity; they insert dorsal and lateral to the mouth opening (Fig. 1 inset). On the frontal side, a prominent ciliary band runs from the base to the tip of the palp and is laterally flanked by additional groups of long and densely arranged cilia, which occur in a regular repeated pattern along the longitudinal axis of the palp.

The palps are hollow appendages equipped with an eccentrically located cylindrical strand of mesodermal tissue supplied with two closely apposed coelomic cavities (Fig. 6). The following tissue layers can be distinguished: epidermis with cuticle and a peritoneum mainly formed by muscle fibers and a few coelothelial cells separated by a prominent ECM.

The epidermis comprises ciliated and unciliated supportive cells, receptor cells, and glandular cells interconnected by typical junctional complexes (Fig. 6). The epithelium of the palp is much thicker on the frontal side than on the afrontal side. On the frontal side, thinner ciliated cells form a distinct groove. All cells and the cuticle exhibit an ultrastructure similar to that on the other appendages. Ciliated supportive cells are restricted to the frontal side; each of the groups of dense and long cilia belongs to a single cell (approximately 3-4 cilia/ $\mathrm{\mu m}^{2}$ and $100 \mathrm{cilia} / \mathrm{cell}$ ). The glandular cells with electron-lucent content open via pores in the frontal cuticle between the less dense ciliated cells. The cell bodies of the gland cells are embedded between those of the supportive cells in the thicker region lateral to the ciliated groove. Numerous receptor cells are distributed between the supportive cells on all sides. In addition, two prominent nerves run laterally within the epidermis along the longitudinal axis of the palp (Fig. 6).

The coelomic cavities are unequal in size; a smaller lateral cavity is separated from the considerably larger median cavity. Their peritoneum mainly comprises musculature compressing the lumen of the cavity. The musculature consists of an outer ring of thinner muscle fibers with circularly orientated myofilaments followed by inner fibers with longitudinally orientated filaments. These longitudinal fibers are arranged in three distinct groups of different diameters, the smallest in the lateral cavity and the other two in the large cavity. The two coelomic cavities are separated from each other by a strand of ECM and a double layer of peritoneal cells. The strand of ECM is connected to the circular ECM surrounding the 
entire mesodermal tissues. Inside this sheet of ECM separating the two coelomic spaces, an additional cavity develops, thus forming a single blind-ending blood vessel supplying the palp.

\section{Branchiae}

The lanceolate finger-like branchiae of $S$. alveolata of the thoracic and parathoracic segments are somewhat smaller, more slender distally but supplied with a larger base than on the following first abdominal segments where the longest branchiae are present (Fig. 1). From there, their size diminishes continuously, and the most posterior ones are just small papillae. Although arising dorsally close to the notopodia from the body wall, they are not part of the parapodia (Figs. 1, 7A, 8A-C). The largest branchiae in the specimens investigated were between 520 and $650 \mu \mathrm{m}$ long and measured approximately 180$200 \mu \mathrm{m}$ by $50 \mu \mathrm{m}$ at their bases with the longer axis perpendicular to the longitudinal body axis. Anatomically all branchiae exhibited the same structure.

In the resting position, the branchiae are somewhat bent forward and to the dorsal midline, thus pointing with their tips towards the openings of the tubes. The most conspicuous external feature is their characteristic ciliation pattern (Figs. 1, 7A-E, 8D, E), comprising several bands of densely arranged motile cilia as well as numerous ciliary patches formed by immotile cilia of receptor cells (Figs. 7A-E, 8D), all of which are arranged in a highly regular and distinct pattern. The motile cilia form two straight longitudinal bands situated on the outer side of each branchia, one of which is located on the outward-facing edge, the other one more anteriorly (Fig. 7A, C). Both bands do not extend to the tip of the branchiae, the latter being somewhat longer. Close to this band, semicircular ciliary bands arise in a more or less regular pattern running on the inner side of the branchiae so that they can hardly be seen if viewed laterally (Figs. 1, 7A-C). These semicircular bands are sickle-shaped with their sagged, concave side oriented towards the body. They are about $50 \mu \mathrm{m}(45-65 \mu \mathrm{m})$ apart from each other, thicker in the middle of each semicircle, becoming thinner at their margins (Figs. 1, 7A-C). Accordingly, their number varies with the length of the branchia considered. The longitudinal bands are somewhat discontinuous with some gaps between the groups of cilia (which become larger towards the tips), and finally, the bands end (Fig. 7A, C). Interposed between these cilia are groups of presumably immotile sensory cilia (Fig. 7B-E). Two groups have been distinguished, one with more numerous and shorter cilia (approximately 10-20 cilia of $1.25-1.5 \mu \mathrm{m}$ ) and another with fewer but longer cilia of different lengths (approximately 5 cilia, 3-6 $\mu \mathrm{m}$ long) (Fig. 7D, E).

In fresh fixed material, the branchiae are yellowish and somehow transparent; thus, their blood vessels are visible under a dissecting microscope (Fig. 8A). Each branchia is supplied by two main vessels, the efferent and afferent vessels of Meyer [17]), here more neutrally called outer and inner branchial vessels according to their position (Suppl. Fig. S1, Suppl. File3 Video). These two vessels proceed towards the tip of the branchia in a hairpin-like arrangement with a pointed tip connecting them distally. In contrast to the coelom, which almost reaches the tip of the branchiae, these vessels do not extend into the approximately uppermost quarter of the branchiae. In most preparations, the outer vessel appeared to be thicker than the inner (Fig. 8A-D). Basally at the level of the body surface, both vessels are interconnected by a distinct connecting vessel (Fig. 8A-C; arrows). This point likewise marks where the branchial coelom 
is separated from the coelom of the trunk (Fig. 8C, Suppl. Fig. S1, Suppl. File3 Video). The outer and the inner branchial vessels extend deeply into the body, and after separately passing the strong dorsal longitudinal musculature, they turn medially towards the midline (Fig. 8B, C). Their connection to the vascular system of the trunk has not been studied.

Within each branchia, these longitudinal blood vessels are frequently connected by transversely oriented ring-like blood spaces situated in the ECM surrounding the branchial coelom (Figs. 8D, 10A, Suppl. Fig. S2). These ring-like blood vessels give rise to further transverse blood spaces extending deep into the branchial epidermis (Figs. 8E, 9A, 10A, Suppl. Fig. S2). These blood spaces are arranged more or less leaf-like and give the branchial blood vascular system a ladder-like appearance (Fig. 8A, E, Suppl. Figs S1, S2, Suppl. File3 Video). Connections to the main vessels and their ring-like connecting vessels are difficult to observe (Figs. 8D, arrowhead, 9A, arrows; Suppl. Fig. S2). The number and density (approximately 1 per $5 \mu \mathrm{m}$ ) of the leaf-like blood spaces are more or less constant from proximal to distal but leave the uppermost part of the branchiae without such blood spaces. When filled with blood, these spaces are up to $5 \mu \mathrm{m}$ wide but may become rather narrow when they are almost empty $(0.4 \mu \mathrm{m}$; Figs. 8D, E, 9A-C). During the former, adjacent blood spaces are rather close to each other (Suppl. Fig. S2). In the epidermis, the blood spaces almost reach the apical cell membrane at certain places; mostly, they terminate between 150-400 $\mathrm{nm}$ below the apical surface (Fig. 9B, C).

The branchiae are innervated by two bundles of nerve fibers originating close together where the dorsal nerve meets the main segmental nerve proceeding from the ventral nerve cord (Fig. 8F). The branchial nerves follow the longitudinal axis of the branchiae and are located on both flattened sides of the coelom in each branchia. They are situated basiepithelially just above the epidermal ECM and are comparatively close to the surface where they cross the intraepithelial blood spaces. They are irregularly interconnected and give rise to numerous dendritic processes with sensory cilia giving the innervation pattern of the branchiae a herringbone-like pattern (Fig. 8F). In addition, some fibers very likely are in contact with the bands of motile cilia (Fig. 8F). The fiber bundles mainly comprise neurites, but a few glial cells were found as well.

As in the other appendages, the epidermis comprises unciliated and ciliated supportive cells, receptor cells, and numerous glandular cells interconnected by typical junctional complexes (Fig. 9A-H, Suppl. Fig. S2). The epidermis is covered by an approximately $1 \mu \mathrm{m}$-thick cuticle exhibiting the same structure as described for the opercular papillae (Fig. 9B, C). Unciliated supportive cells are the most abundant cell type. The cells are characterized by a comparatively electron-lucent cytoplasm poor in organelles and nuclei appearing lighter than those of the other cells. The nuclei are located in larger portions of the cells located between the blood spaces (Fig. 9A, Suppl. Fig. S2). In these regions, the epithelium may be approximately 10-15 $\mu \mathrm{m}$ thick. However, above the main blood vessels, the epidermis may be only approximately 2.5-3 $\mu \mathrm{m}$ thick (Suppl. Fig. S2).

Proximally in the branchiae, numerous gland cells are interposed between the supportive cells. There are 1-2 gland cells in each fold between two blood spaces. More distally, the number of glandular cells 
decreases (Suppl. Fig. S2). In contrast to the body wall, only two types of glandular cells were found. The nuclei were situated basally in the cell bodies and contained more heterochromatin than found in the supportive cells. The more frequent type is characterized by an almost electron-lucent secretion which occupies a large part of the cell. The mature secretion appeared to form a coalesced mass with some discontinuous membranes in between. These cells form $2 \mu \mathrm{m}$-wide necks reaching the apical level of the epidermis (Fig. 9E). The other gland cell type is characterized by membrane-bounded secretory granules $(\sim 1.5 \times 2 \mu \mathrm{m})$ with granular contents of medium electron density (Fig. 9E). These gland cells possess elongated necks as well, the uppermost approximately $4 \mu \mathrm{m}$ form characteristic apertures (Fig. 9E). Although the junctional complexes are situated at the level of the epidermal supportive cells, the apical membrane of the gland cell forms a cylindrical depression of the apical membrane (Fig. 9E). The cytoplasmic cylinder surrounding the $1.5 \mu \mathrm{m}$-wide depression is only $150-350 \mathrm{~nm}$ thick. Inside this depression, numerous small vesicle-like particles have been found. In both cell types, circularly arranged microvilli were not observed. Likewise, the cuticle was not modified above the gland cells. Often a receptor cell process was found close to the gland cell openings (Fig. 9E).

The curved ciliary bands are usually formed by rows of cells only one cell wide on their narrow axis (Fig. 9E, Suppl. Fig. S2). The straight bands may comprise more cells (Fig. 8D, E, 9E, Suppl. Fig. S2). Depending on the width of the ciliary band, the cells bear rows of approximately 8 to 16 cilia; there are approximately 7 cilia per $\mu \mathrm{m}^{2}$. Each cell may bear more than 100 cilia. The cilia are anchored in the cytoplasm by a prominent rootlet system comprising a longer rootlet extending for approximately 3.5$4 \mu \mathrm{m}$ into the cell and a shorter rootlet parallel to the apical cell membrane (Fig. 9D). The rootlet system continues in the basal-apical filament system. Between the rootlets, numerous mitochondria were found. Generally, the cells are trapezoid in cross-section and are broadly anchored on the ECM (Fig. 9D). The nuclei are typically situated laterally to the cilia (Suppl. Fig. S2). Due to their high content in filamentous structures and mitochondria, these cells appear more electron-dense than the unciliated supportive cells.

The receptor cells are typical bipolar cells with their cell bodies situated between the epidermal supportive cells (Fig. 9F, Suppl. Fig. S2). Usually, they form small groups of a few cells. Multiciliated and uniciliated receptor cells were found, all with cilia penetrating the cuticle (Fig. 9F-H). The multiciliated cells bear approximately 6 cilia. The cilia possess a $9 \times 2+2$ axoneme and are anchored by a basal body extending above the cell surface for approximately half their length (Fig. $9 \mathrm{H}$ ). To these basal bodies, small indistinct rootlets are attached in the multiciliated cells (Fig. 9G). In the dendritic processes, flat cisternae of agranular endoplasmic reticulum are presented close to the cell membrane. In addition, microtubules following the longitudinal axis of the processes, mitochondria, and multivesicular bodies were found (Fig. 9G).

The epidermal cells rest on a continuous ECM approximately $100 \mathrm{~nm}$ thick (Figs. 9A-D, 10A). This ECM also lines the blood spaces bulging into the epidermis (Fig. 9B, C). A similar ECM is present between the peritoneum and the main blood vessels. Thus, the blood vessels represent spaces in the ECM of the epidermis (Fig. 9B, C) or the ECM between the epidermis and peritoneal cells (Figs. 9A, 10A-G). In the 
areas around the main blood vessels, a network of distinct fibers has been observed just above the ECM in the blood (Fig. 10G).

The peritoneum is formed by either rather flat sheet-like cells lining the coelom only $30 \mathrm{~nm}$ thick in certain areas without nuclei or myofilaments (Fig. 10F, Suppl. Fig. S2) or by cells with larger cell bodies appearing granulocyte-like (Fig. 10D, Suppl. Fig. S2). All cells form a typical epithelium connected by zonulae adherentes and septate junctions (Fig. 10D, E). The sheet-like cells contain bundles of myofilaments following the main axes of the blood vessels (Fig. 10F, G). In these areas, the cells are much thicker (300-400 nm). Depending on their contraction, the cells may form folds extending into the blood vessels (Fig. 10E). The granulocyte-like cells are only present in the peritoneum above the two main blood vessels. They contain numerous electron-dense vesicles of unknown contents (Fig. 10D).

Processes of the flattened peritoneal cells with myofilaments extend between these cells (Fig. 10D, inset). Occasionally blood cells were found (Fig. 10A-C, Suppl. Fig. S2). These are characterized by a compact cell body containing the nucleus and irregularly shaped flat processes. They are not lined by an ECM and border the blood directly (Fig. 10B, C). On the processes, numerous coated pits and vesicles, as well as early endosomes, were found (Fig. 10C). Larger vesicles of the lysosomal system showing different contents were found in the cell bodies (Suppl. Fig. S2).

\section{Discussion}

\section{General aspects}

Due to their specific and highly specialized morphology and biology, Sabellariidae, also known as honeycomb or sandcastle worms, have received special attention since their first description in the 18th century [3]. This interest may be based on the fact that many species are gregarious, building extensive reefs, and thus, they are the major component of specific biocenoses. The division of their body into an operculum, parathorax, abdomen, and cauda is one of the main characteristics of the taxon [2-4]. Sometimes the operculum is further divided into the operculum proper and thorax [6]. Whereas their external morphology is well-known and has been described repeatedly, only a few studies have examined the internal morphology, ultrastructure, and functional morphology [6, 9]. This scarcity of knowledge likewise applies to the various kinds of appendages. In addition to the parapodia, Sabellariids bear four different kinds of appendages, three of which are related to the anterior end or operculum, namely the opercular papillae, the tentacular filaments, and the palps. Only the branchiae are related to the trunk segments. Out of these appendages, merely the ultrastructure and functional morphology of the palps in larval Phragmatopoma californica have been studied thus far $[15,16]$.

All four types of appendages studied comprise epidermal and mesodermal tissues. Whereas epidermis and cuticle are structurally more uniform, the mesodermal structures differ between the four types of appendages. They may comprise connective tissue, muscle fibers, and coelomic cavities, as well as blood vessels. However, blood vessels and coelomic cavities were not observed in the opercular papillae, blood 
vessels are absent in the tentacular filaments, and coelomic cavities and blood vessels are only present in the palps and branchiae.

Epidermis and Cuticle. In all appendages investigated, the epidermis comprises just a few and similar cell types. These include unciliated and ciliated supportive cells, gland cells, and several types of receptor cells. However, ciliated supportive cells with motile cilia are only present on the tentacular filaments, palps, and branchiae. Typical for multiciliated cells in annelids, accessory centrioles are lacking, and the basal bodies are equipped with two striated rootlets, a short one parallel to the apical membrane and a long one extending deep into the cell body and anchoring the cilium [25]. The density of cilia has only rarely been determined for annelid epithelia [25-27] but in the appendages of $S$. alveolata, it is similar to that of pharyngeal epithelia of other annelids with reported densities of up to $6.5-8.5$ cilia per $\mu \mathrm{m}^{2}$ [28, 29]. In these cells, more than 100 cilia per cell may be present [29]. Such densely arranged cilia have been termed compound cilia and the respective cells ciliophores, if these cilia are anchored by long rootlets and more than 100 cilia per cell are present $[14,27,30]$. However, there are no ultrastructural differences from other ciliated cells, and thus justification of this separation and term appears to be questionable. Generally, densely ciliated cells are present on epithelia transporting and collecting materials as well as on epithelia generating water currents for ventilating the branchiae or swimming. The functional significance of the varying density was not addressed.

The general organization of the epidermis is similar to that of polychaetous annelids except for the structure of the cuticle $[25,26]$. This organization includes the presence of secretory cells, which are generally abundant in the annelid epidermis [25]. Due to their different functions, gland cells and their secretion exhibit a high structural diversity, as can be observed in their apical apertures. Depending on the fine structure of the cuticle, these often comprise multiple circular microvilli leaving a more or less distinct central pore in the cuticle for the release of secretions [25].

In S. alveolata, the epidermis is covered by a cuticle, similar to a larval cuticle of other annelids in the absence of layers of parallel collagen fibers. Such layers are usually the most characteristic feature of the cuticle in adult annelids of comparable body size [25, 26, 31]. Other sabellariids studied thus far show a similar pattern of cuticular ultrastructure $[6,9-11,14,15]$. In addition to Sabellariidae, other exceptions to this general pattern are polychaetes having meiofaunal body dimensions and several members of the socalled basal radiation $[32,33]$ such as Oweniidae, Magelonidae, Chaetopteridae, Psammodrilidae and Apistobranchidae $[25,34-36]$.

Likewise, there are no differences in the structure of the cuticle between the different body appendages studied here, the operculum or the trunk in S. alveolata $[6,26]$. In species possessing a cuticle with collagen fibers, the thickness of the branchial cuticle is considerably less, and collagen fibers are reduced or even absent $[21,22,37,38]$. Most likely, this is indicative that in Sabellariidae the cuticle does not provide a real barrier for the exchange of molecules with the surrounding environment and there seems to be no functional necessity for a thinner or specialized cuticle in epithelia adapted to gas exchange (see also [6]). 
In general, the annelid cuticle is a flexible and soft structure through which many substances may diffuse rather than a tight border as the term cuticle may suggest $[25,31,39]$. Moreover, the cuticle is regularly traversed by more or less densely arranged microvilli, their apices forming a cover above the cuticle proper and in direct contact with the environment. The weak structure of the cuticle might also be an adaptation to the tubicolous lifestyle of all Sabellariidae, which cannot survive outside their tubes after settlement [3]. Thus, their elaborate and firm tubes may have partly taken over the protective role of the cuticle. Absence of collagen fibers and thus similar cuticular features has also been reported for a few species of tubicolous Sabellidae and Serpulidae [40].

Receptor cells. Receptor cells occur everywhere in the epidermis of annelids, but on the various types of appendages, they are often present in higher numbers [25,41]. Therefore, appendages rich in receptor cells are generally regarded as sensory organs like the antennae, palps, parapodial, and anal cirri [41-43, 45]. On the body and the appendages, the receptor cells may occur scattered between supportive cells or clustered in small groups of mostly just a few cells. These cells are bipolar sensory cells, and their somata are either located in the epidermis or are situated deeper in the body within the nervous system.

The dendritic processes of the receptor cells are generally ciliated, and accordingly, they are often classified by the number of cilia present and whether or not these cilia penetrate the cuticle [43]. The latter, usually called non-penetrative receptor cells, were not encountered on the structures investigated in S. alveolata. Due to their fine structure, receptor cells may be further subdivided into several subtypes [36, 44]. Structural diversity is generally interpreted as indicative of different sensory stimuli or different sensitivity, although the function of these receptor cells is still insufficiently known and mainly speculative $[22,41]$.

Among the receptor cell types present in S. alveolata, uniciliated sensory cells predominate. Usually, the latter are characterized by a dendritic process diminishing apically in diameter to approximately $1 \mu \mathrm{m}$ or less, and thus they form tufts of densely arranged sensory cilia that cannot be assigned to a certain number of cells if viewed with SEM. Moreover, such cells intermingle with multiciliated receptor cells possessing a wider cell apex. As a rule, these receptor cells possess microvilli accompanying and surrounding the cilia $[41,43,45]$. One specific receptor cell type of this kind exhibits 8 or 10 strong microvilli forming a regular crown around the single cilium and is usually called a collar receptor [46]. Collar receptors frequently occur in aquatic invertebrates and are the characteristic elements of lateral polychaete organs, representing a typical sensory organ present in many sedentary annelids [36, 41, 43]. Unexpectedly these are obviously absent in the appendages of $S$. alveolata. Compared to purely sensory appendages of other polychaetes, the receptor cell diversity appears to be lower in $S$. alveolata. However, it should be noted that only very few species have been investigated for these features [22, 44, 47-51]. These results are consistent with investigations on the median organ in S. alveolata and Idanthyrsus australensis (Haswell, 1883), and the palps of larvae in Phragmatopoma californica (Fewkes, 1889) and Phragmatopoma caudata Krøyer in Mörch, 1863 [as P. lapidosa Kinberg, 1866] [6, 9, 19, 15, 16]. However, in the latter two species, only multiciliated receptor cells have been identified, and probable occurrence of 
uniciliated cells is not mentioned $[10,15,16]$ Thus, the paucity of morphologically distinct ciliated receptor cell types appears to be a general feature of Sabellariidae.

\section{Opercular papillae}

A ring of opercular papillae situated immediately beneath the paleae is generally present in members of Sabellariidae [1, 3]. Usually, these papillae are numerous, differing in number, size, and form according to the species and age of the individual considered [2]. The highest numbers recorded are approximately 20 pairs as observed in our material of $S$. alveolata, and, for instance, up to 18 pairs have been reported in Lygdamis wambiri [1]. The number of papillae is age-dependent, and the development of these papillae starts with only one pair in late larvae $[9,52]$. In larger specimens, they are often not easy to count, especially if prepared and mounted for SEM. This challenge might be the main reason why so few authors provide numbers in their descriptions as, for instance, in Capa et al. 2015 [2]. Although these appendages were noted in certain previous studies on the morphology of the anterior end [19,53], a more precise view of the structure of these appendages was thus far unknown. If viewed with SEM, the opercular papillae with their tufts of sensory cilia distributed all around them (e.g., our Fig. 2B; Fig. 1 in [15]; Fig. 2d, e in [9]) somehow resemble parapodial cirri of other polychaetes [22, 41]. Accordingly, the first pair of these appendages appearing in late pelagic larvae in close proximity to the provisional chaetae has been called cirri or opercular cirri $[10,15,52,54]$. Somewhat later, after metamorphosis has started, and the provisional chaetae have been replaced, these cirri are situated beneath the first formed paleae and become the first pair of opercular papillae $[9,52]$.

Generally, the opercular papillae can be classified as outgrowths of the anterior body wall. Due to the presence of connective tissue and musculature, the appendages are moveable structures. In the adult worms, the opercular papillae are situated close to the foremost position of the sabellariid body. Together with the tentacular filaments, the opercular papillae represent those structures which are most likely the first to come in contact with all kinds of potential sensory stimuli when the animals open the operculum and are in the feeding position (see supplementary video in Meyer et al. 2019 [6], [55]). In the absence of coelom, blood vessels and motile cilia indicate that the papillae are neither involved in feeding nor respiration. Instead, the high number of tufts of sensory cilia likely indicates a predominantly sensory function, irrespective of the fact that the receptor cell diversity is lower as in the appendages of the few errant polychaetes studied for this character $[22,47,56]$. Regarding receptor cell diversity and density, sabellariids notably have a completely different life strategy combined with immobility, requiring a different and specific adapted sensory system $[5,6,9]$. Whereas the median organ is most likely involved in triggering of the shadow reflex $[2,5,6]$, mechanical or chemical stimuli may play a significant role in the function of the opercular papillae including triggering the withdrawal of the animal into its tube. Unfortunately, our immunostainings did not allow for clarification of the innervation pattern of these appendages, but we assume that the various nerve tracts innervating the operculum as described and imaged by Orrhage [19] include the efferent fibers of the receptor cells. Out of these, the nerves innervating the lateral parts of the operculum or the outer paleae (nmlo1, nmlo2, and nmoop in [19]) appear to be the best candidates for this function. All nerves innervating the corresponding part of the 
operculum have been shown to represent parapodial nerves emanating outside the brain from the central nervous system by Orrhage [19].

\section{Tentacular filaments}

Filamentous appendages inserting on the ventral and inner side of the operculum are present in most sabellariid species except for those of Phalacrostemma [1,3]. These branched or unbranched appendages are commonly called tentacular or oral filaments and may occur in high numbers, as is the case in $S$. alveolata $[3,19]$. They are involved in the transport of food particles to the mouth and sediment particles for tube construction to the building organ on the ventral side $[3,14,19,55,57,58]$. The particle transport mechanism has been analyzed in high-speed video recordings $[14,55,58]$. In active animals, these appendages are exposed to the exterior and are widely stretched out into the surrounding medium ([55]; see Fig. 1A-D in [5], and supplementary video [6]). As discussed for the opercular papillae, the tentacular filaments are thus the second type of anterior appendage coming in contact with various sensory stimuli and are most likely important sensory structures as well. However, their extensive ciliation, in addition to the sensory cells, speaks in favor of a double function: sensing as well as particle selection and collection.

The external morphology and the histology of the tentacular filaments are comparatively well known [14, $18,19,55,58,59]$. These observations are complemented by preliminary ultrastructural observations of the tentacular filaments by Riisgård and Nielsen [14]. We confirm in our present investigation the general structure of the ciliation pattern of these appendages and clarify some discrepancies. In all studies, frontal cilia have been described as forming a continuous ciliary band, and a more or less distinct groove is formed proximally, which is absent distally [19]. These cilia are supplemented by longer cilia extending laterally from this band. As noted by Riisgård and Nielsen [14], these are made up of three bundles of cilia, each of which belongs to a single cell. So these lateral cilia are formed by three longitudinal rows of densely ciliated cells separated by unciliated cells at regular intervals. These cilia have been called compound cilia, spikes, or grouped frontal and lateral cilia $[14,55,58]$. However, there is no structural evidence that these cilia are somehow structurally interconnected [58].

As in the studies of Dubois et al. [55,58], we were not able to detect the so-called cirri, somehow separated smaller bundles of long cilia adjacent to the lateral groups of dense cilia, described by Riisgård and Nielsen [14]. It has been argued that they represent artifacts [58]. From live and recorded video observations, it is evident that the lateral grouped cilia often project orthogonally from the surface of the tentacular filaments and appear to be immobile $[14,55,58]$. Nevertheless, according to Riisgård and Nielsen [14], these cilia sporadically bend in the downward longitudinal direction of the tentacular filament. Movability of these cilia has been confirmed, but the direction of ciliary movement has been observed as oblique towards the frontal surface by Dubois et al. [55, 58]. In any case, these previous observations of the activity of these cilia are consistent with our findings on the innervation pattern, strongly suggesting that beating of these long cilia is under nervous control. 
Most authors observed that the epidermis is thicker on the frontal side, where the ciliated cells are located $[14,19,59]$. Glandular cells have also only been found on the frontal ciliated side and have been shown to represent only acid mucopolysaccharides belonging to a single type [55]. The conspicuous gutter-like structure situated beneath the epidermis confirms their hyaline cartilaginous nature [14, 19]. However, in contrast to Riisgård and Nielsen [14], it is not part of the basal membrane or ECM, but rather, clearly separated from the ECM and situated beneath it. Likewise, the views that this structure is an artifact and represents an extraordinarily distended basal lamina [58] or represents blood vessels [18] have to be rejected. Since it is entirely cell-free, it should not be termed connective tissue. The two ends of the " $\mathrm{U}$ " on the frontal side are connected by the ECM surrounding the entire element. Here it is underlined only by muscle fibers; the presence of a ligament-like structure as discussed by Orrhage [19] cannot be confirmed or may be represented by the ECM.

The movability of the tentacular filaments has been described in detail [14]. Most likely, this movability is due to their cartilaginous structure in combination with the central musculature enclosed by the cartilaginous structure. In this musculature, longitudinal fibers predominate, and these may be responsible for bending the tip, followed by a spiral contraction of the entire tentacle [14]. Stretching might be a more passive process mainly mediated by the cartilaginous structure serving as a kind of flexible skeletal element. The small additional longitudinal fibers situated on the outer side of the cartilaginous structure are described here for the first time. Observations of the presence or absence of food particles in the surrounding medium are correlated with the motion of the tentacles. Furthermore, their ciliation supports our view that the entire system is under nervous control and that at least in part, the different receptor cells present on these filaments are responsible for the necessary sensory input to trigger the uptake of particles.

We can confirm the presence of a coelomic cavity noted by Orrhage [19]. Typical epithelial junctional complexes are present, demonstrating that these spaces represent coelomic cavities sealed by a myoepithelium [60-62]. However, blind-ending blood vessels, as described in the older literature, are definitely absent in the tentacular filaments [17-19] and most likely the cartilaginous structure was mistaken as blood space. Thus a prominent role in gas exchange can be excluded. Whether these appendages are homologous to branchiae or unique for Sabellariidae as discussed by Rouse and Pleijel [4] appears to be answered by the latter hypothesis given their different structure and especially the lack of blood vessels and blood supply.

\section{Palps}

The presence of two so-called peristomal palps in larval and adult members of the Sabellariidae has already been observed $[2,7,19]$ and their function in chemo- and mechanoreception as well as in feeding behavior assessed $[10,14,15,54,63]$. However, ultrastructural analyses of adult palps are rare and mainly based on light microscopic observations $[19,55]$ or focus on the larval palps $[15]$.

The present ultrastructural analysis of the palps of adult $S$. alveolata shows strong similarities to the structure of the larval palps of Phragmatopoma californica [15]. In brief, the palp is ciliated and grooved 
on the frontal side along the longitudinal axis and exhibits two coelomic cavities separated by a single blood vessel and surrounded by mesodermal cells and ECM. Within the epithelium, two prominent nerves are present. This pattern is somewhat similar to earlier descriptions of sabellariid palps $[15,18,19,59]$ and is similar to other grooved palps $[4,64,65]$.

The palps of $S$. alveolata and other sabellariids are multifunctional organs that might have different tasks regarding the developmental stage of the animal. In larval stages, it is assumed that they have a minor part in feeding but mainly function in mechano- and chemoreception. The prominent ciliary band and additional groups of cilia, in combination with the presence of gland cells, make them a highly suitable structure for locomotion [66]. In late larval and juvenile stages, the palps might be responsible for substrate recognition, settlement and the building of the tube, as they sense different chemical signals allowing the animals to recognize others and attach their tube, thus forming the famous large reefs [67, 68].

\section{Branchiae}

Annelid branchiae. In annelids, gas exchange may occur through the entire body wall, parapodia, or specialized organs commonly termed branchiae or gills $[4,20,21,69]$. Polychaete branchiae are generally outgrowths or extensions of the body wall often associated with the parapodia or arising separately from the dorsum $[4,20,69]$. As such, they are composed of epidermis, nerve fibers and receptor cells, blood vessels, musculature, and often coelomic cavities. The occurrence of branchiae is restricted to specific taxa, and especially polychaetes with small body dimensions often don't possess branchiae. In Clitellata, branchiae are usually absent, and their occurrence is a rare exception $[70,71]$. In polychaetes, they are generally found in Amphinomidae, certain Errantia, and many Sedentaria[4, 20, 72]. Probably due to their non-uniform occurrence, they exhibit a certain diversity in structure, form, and position, although several common features have been recognized. The highest complexity thus far has been observed in hydrothermal vent annelids and Siboglinidae [38, 44, 73-75].

Thus far, the ultrastructure of polychaete branchiae has been studied in multiple species, not representing close to the entire range of taxa possessing these organs [4, 20-22, 38, 44, 75-79]. Possibly the entire range of diversity may still not be known. Furthermore, recent investigations indicate that our knowledge of several species investigated previously may still be incomplete [21, 22].

Besides the mentioned diversity, polychaete branchiae show several common features: most polychaete branchiae studied so far are equipped with numerous motile cilia arranged in bands or tufts responsible for generating water currents for an effective, continuous, and powerful exchange of the surrounding water [20]. Thus, the elaboration of concentration gradients above the respiratory surfaces is avoided. In addition, the cuticle is generally thinner above the respiratory epithelia than in other body regions. Polychaete branchiae usually contain a loop of blood vessels giving rise to capillaries basally extending into the epidermal cells $[4,20,69,72]$. The vessels of this loop are commonly termed afferent and efferent vessels, and within the branchiae, they are differently interconnected. From these vessels, more or less numerous blood spaces or sinuses extend into the epidermis, making the diffusion distances as small as 
possible. In most cases, the branchiae include mesodermal structures such as muscle fibers and often coelomic spaces. Lastly, branchiae are innervated and bear numerous receptor cells.

Stekolshchikov [80] and Storch and Alberti [82] attempted to assign the diversity of annelid branchiae to three or four different types, respectively. The pros and cons of these classifications were discussed by Belova and Zhadan [21], and it was concluded that this needed revision. Based on the data available, we suggest that the annelid branchiae may be divided into three different types.

1. 1. Branchiae with coelom and blood vessels: as in S. alveolata, a coelomic cavity following the main blood vessels has been observed in many species [21, 37, 38, 76, 79, 82, 83]. In contrast to the hydrothermal vent Terebellida, the absence of a coelomic cavity has been reported in the intertidal Terebella haplochaeta by Wells et al. [81], but very likely this is due to a misinterpretation of their histological sections (see, e.g., Fig. 12 in [81]). It is unknown whether the coelomic cavities are continuous with the segmental coelom in these species or whether they are separate, as observed in the present study. If the branchiae bear lamellae, filaments, pinnules, and other structures, the coelomic cavity or muscle fibers may reach into these branches $[38,79]$ or simply comprise epidermal structures with extensions of the blood vessels bulging into the ECM of the epidermis [74]. This latter feature has been observed in the branchial leaflets of Lagis koreni Malmgren, 1866 [as Pectinaria koreni], and most likely, it was erroneously described as a separate type of branchiae by Storch and Alberti [82].

2. 2. Branchiae with mesodermal tissue and blood vessels: more rarely, the space between the two main vessels is completely occupied by mesodermal cells, mainly musculature $[22,78]$. Thus far, this latter pattern has only been found in Amphinomidae and Orbiniidae.

3. 3. Coelomic branchiae: In certain species with a reduced or absent blood vascular system, the coelom may take over the function of the blood vascular system [77]. Consequently, branchiae, if present, are of different structure and commonly called coelomic branchiae such as those occurring in glycerids and hydrothermal vent polynoids [77]. These species usually appear red due to the presence of hemoglobin in the coelomic fluid or the coelomocytes.

Sabellaria Branchiae. In S. alveolata, the branchiae exhibit the densest ciliation pattern observed, exceeding those of the tentacular filaments and palps. In contrast to the latter appendages, only one pattern of density has been observed. Data on the cellular level of the ciliatation in branchiae are rare; mostly, it is mentioned that a dense ciliation is present [38, 75, 82]. Estimations made based on published micrographs on ciliated cells leads us to assume that the density observed in $S$. alveolata appears to be among the highest described [22]. As in S. alveolata, each ciliary band is formed by a single row of ciliated cells in most other polychaetes, such as in the amphimonid Eurythoe complanata (Pallas, 1766), the polynoid Branchipolynoe sp. and in the ophelliids Ophelia limacina (Rathke, 1843), Ophelina acuminata Örsted, 1843 and Euzonus arcticus Grube, 1866 [21, 22, 77]. This feature is probably characteristic of alvinellids and trichobranchids, although not explicitly mentioned [38, 79]. In contrast, in an undescribed deep-sea orbiniid, the ciliary band is formed by several rows of cells [78]. This can be confirmed by our unpublished data on the intertidal Scoloplos armiger (Müller, 1776), and thus far, 
Orbiniidae appears to be the only diverging example. In annelids, only three species have been described thus far possessing branchiae without cilia: Sternaspis scutata (Ranzani, 1817), Travisia forbesii Johnston, 1840 and Arenicola marina (Linnaeus, 1758) [21, 37, 76]. In these species, ventilator currents are solely generated by the peristaltic movements of the body wall [37].

As a rule, the cuticle and epidermis are considerably thinner on branchiae than on other parts of the body $[21,22,37,78]$. Besides reduction of total thickness, mostly between 1-2 $\mu \mathrm{m}$, the number of layers of parallel collagen fibers forming a net-like structure is reduced, or even lacking $[22,25,76]$. On initial observation, $S$. alveolata does not seem to follow this general pattern, since its cuticle is of similar thickness on all body regions. However, as discussed above in S. alveolata and other sabellariids studied thus far, the entire cuticle is highly reduced.

Except for noting the occurrence of receptor cells and neurite bundles [37, 38, 75, 82, 84], innervation of branchiae has usually not been studied in detail. Receptor cells found on branchiae usually have cilia penetrating the cuticle, and the formation of small groups of uniciliated and multiciliated receptor cells has been described [22, 44]. Multiciliated cells are most common in Paralvinella hess/eri Desbruyères \& Laubier, 1989 (Alvinellidae), whereas in Eurythoe complanata (Amphinomidae) uniciliated receptor cells predominate. Our findings for $S$. alveolata most closely resemble the former scenario. However, it must be noted that very few species have been studied.

The innervation of the branchiae usually originates from the ventral cord via the segmental nerves $[22,44$, 85]. In Eurythoe complanata, the branchial nerve branches off from the main segmental nerve, which innervates the parapodium and also comprises efferent fibers from the dorsal cirrus. This situation appears to be similar in Terebellides cf. stroemii Sars, 1835 (Trichobranchidae), Cossura pygodactyla Jones, 1956 (Cossuridae) and Paralvinella hessleri (Alvinellidae) [44, 85]. Depending on the structure of the respective branchiae, these nerves may split within the branchiae as in $S$. alveolata, wherein the two nerves mark the extension of the branchial coelomic cavity. In E. complanata, the motile cilia are innervated by separate neurite bundles [22], which is not the case in the other species studied, including $S$. alveolata.

In annelids possessing a blood vascular system, the branchiae are supplied by efferent and afferent vessels, which in the branchiae are variously connected and often give rise to blind-ending blood spaces (blood sinus). The latter often extend deep into the basal regions of epidermal supportive cells [21-23, 37, 82]. Efferent and afferent vessels unite distally, occasionally forming a long hairpin-like, blind-ending loop as, for example, observed in Eurythoe complanata or Osedax mucofloris Glover, Kallstrom, Smith \& Dahlgren, $2005[22,75]$ and in the present study. Thus, blood is driven back into the body by contraction of the branchial musculature, which is present at least along these main vessels. The diffusion distances are often calculated to be $1-3 \mu \mathrm{m}[21,38,79]$. However, in such measurements, generally, the thickness of the cuticle is included, which might not be accurate since, as discussed above, the cuticle in these areas very likely does not form a diffusion barrier. More reliable might be those values including the smallest thickness of only the epidermal cells where the blind-ending blood spaces most closely 
approach the apical side. In doing so, values of diffusion distances diminish to approximately 130$350 \mathrm{~nm}[22,23,38]$, within the same range as that observed in S. alveolata. The micrographs published suggest that this also applies to other species $[21,38]$. Outside such lacunae and sinuses, the thickness of the epidermis is reported to be approximately $5-10 \mu \mathrm{m}$, twice that of $S$. alveolata.

The structure of the blood spaces and blood vessels in S. alveolata is typical for coelomate invertebrates in general; they are lined by the ECM of the adjacent epithelia, and an endothelium is always absent [37, $60,72,86-88]$. The ECM surrounding the afferent and efferent vessels is usually lined by peritoneal and epidermal cells or only by peritoneal cells $[21,22,37,38]$. The peritoneal cells, or part of them, are usually differentiated as myoepithelial cells, and these cells are responsible for the blood flow inside the branchiae. The same is true for the loops connecting afferent and efferent vessels, whereas the terminal branches (blood spaces or sinus) may only be lined by epidermal cells and, as such are non-contractile. Hemoglobin is usually extracellular in annelids, and only a few cells present in the blood. The blood cells or hemocytes present in $S$. alveolata exhibit the same structure and high endocytic activity observed in other species $[21,37,89]$.

\section{Conclusions}

In the reef-building polychaete Sabellaria alveolata, the entire body is covered by a thin and delicate cuticle characterized by the absence of layers of parallel collagen fibers, most likely responsible for the lack of differentiation between the various body regions including the branchiae. All appendages, including the branchiae, bear receptor cells and, as such, are sensory. The opercular papillae with their tufts of receptor cells and lack of motile cilia resemble parapodial cirri of other polychaetes, and their main function may be sensory. In contrast, the tentacular cirri have a double function; sensing and collecting and transporting particles. A similarity to branchiae can be excluded since blood vessels are absent. Besides their distinctive ciliation pattern, the most conspicuous morphological feature is their cellfree endoskeletal cartilaginous structure enclosed by ECM. The palps represent typical grooved palps with two coelomic cavities and a single blind-ending blood vessel $[4,64,65]$. They are adapted for collecting and transporting particles as well as for sensing. The palps are structurally similar to those of other sabellariids studied $[15,16]$. A revised classification of polychaete branchiae is suggested; the branchiae of $S$. alveolata belong to the most common type comprising musculature, coelom, and blood vessels. The branchiae are highly vascularized and equipped with numerous blood spaces extending deep into the basal region of the epidermal cells resulting in short diffusion distances between blood and environment of $150-400 \mathrm{~nm}$.

\section{Material And Methods}

\section{Material}

Adult specimens of Sabellaria alveolata (Linnaeus, 1767) were collected at Saint-Efflam (Brittany, France) in summer 2017. Additional specimens were collected from reefs at Mont St. Michel Bay (Normandy, 
France; collected and fixed by Dr. Larisse Faroni-Perez). Parts of the reefs were dislodged and reared in the laboratory under running seawater until further processing. Animals were removed from their tubes by carefully crashing the walls. Only intact individuals were used for fixation, which occurred at the Marine Biological Station of Roscoff (Brittany, France).

\section{Electron microscopy, semithin sections, and histology}

The smallest adult individuals were chosen for fixation. Specimens from St. Efflam were relaxed in $8 \%$ magnesium chloride $\left(\mathrm{MgCl}_{2} \times 10 \mathrm{H}_{2} \mathrm{O} ; 15 \mathrm{~min}\right)$ isotonic with seawater, and fixed immediately in a phosphate-buffered $(0.075 \mathrm{M})$ solution of picric acid, paraformaldehyde, and glutaraldehyde adjusted to the appropriate osmolality with sucrose (SPAFG, [90]) for $2 \mathrm{~h}$ at $4^{\circ} \mathrm{C}$. Specimens from Mont St. Michel were fixed in $2.5 \%$ glutaraldehyde in $0.05 \mathrm{M}$ phosphate buffer with $0.3 \mathrm{M} \mathrm{NaCl}$. After five rinses in the appropriate buffer for $10 \mathrm{~min}$ each, specimens were stored in the same buffer containing $0.05 \% \mathrm{NaN}_{3}$ at $4^{\circ} \mathrm{C}$. After a few days, they were further processed in the lab of the Zoology department, Osnabrueck. Specimens were then post-fixed in $1 \% \mathrm{OsO}_{4}$ (phosphate-buffered) for $1 \mathrm{~h}$ at $4^{\circ} \mathrm{C}$. After being washed for $5 \mathrm{~min}$ in either $0,075 \mathrm{M}$ buffer adjusted with sucrose or $0.05 \mathrm{M}$ buffer adjusted with $\mathrm{NaCl}$, samples were dehydrated using an EtOH series $\left(30 \%\right.$ for $5 \mathrm{~min}$ at $4^{\circ} \mathrm{C}, 50 \%$ for $5 \mathrm{~min}$ at $4^{\circ} \mathrm{C}, 70 \%$ for $10 \mathrm{~min} 4^{\circ} \mathrm{C}, 80 \%$ for $10 \mathrm{~min}$ at $4^{\circ} \mathrm{C}, 95 \%$ for $10 \mathrm{~min}$ at $4^{\circ} \mathrm{C}, 95 \%$ for $10 \mathrm{~min}$ at RT, and finally, $2 \times 100 \%$ at $10 \mathrm{~min}$ for RT).

Specimens for scanning electron microscopy (SEM) were then critical-point dried using $\mathrm{CO}_{2}(\mathrm{I})$ (CPD 030, Bal-Tec, Präffikon, Switzerland), mounted with adhesive tabs on aluminum stubs, coated with platinum/iridium (sputter coater K575, Emitech, Montigny de Bretonneux, France) and examined with a Zeiss Auriga (Oberkochen, Germany) scanning electron microscope.

For transmission electron microscopy (TEM) and semithin sectioning histology, the smallest specimens available were chosen. They were dissected into smaller parts. These were transferred into a solution of ethanol and the intermedium propylene oxide (100\% EtOH: propylene oxide 1:1, $2 \times 30 \mathrm{~min})$ followed by pure propylene oxide $(4 \times 15 \mathrm{~min})$. This solution was replaced by mixtures of the intermedium and the embedding medium starting with propylene oxide: Araldite/Epon (PolyBed 812) 3:1 for 6h, followed by 2:1 (12h) and finally 1:1 (12h). The intermedium was then allowed to evaporate overnight. Before final embedding, specimens were transferred into drops of fresh Araldite/Epon for $5 \mathrm{~min}$ at $60^{\circ} \mathrm{C}$. After two repeats, specimens were placed in embedding molds. Polymerization was conducted at $60^{\circ} \mathrm{C}$ for $72 \mathrm{~h}$. Specimens were either cut in a series of semithin $(1 \mu \mathrm{m})$ or ultrathin sections $(70 \mathrm{~nm})$ using diamond knives (Diatome, Biel, Switzerland) and UC6 or UC7 Leica ultra-microtomes (Wetzlar, Germany).

A series of ultrathin sections were placed on single-slot grids coated with pioloform support films, then contrasted at $20^{\circ} \mathrm{C}$ with $2 \%$ uranyl acetate $(30 \mathrm{~min})$ and $0.5 \%$ lead citrate $(20 \mathrm{~min})$ in a nanofilm surface analysis ultrastainer (Göttingen, Germany). Finally, the sections were examined with Zeiss EM 902A and Zeiss Libra 120 transmission electron microscopes (Oberkochen, Germany). Images were recorded using CCD cameras (Image SP®, 4k, Mohrenweis, Germany). 
A series of semithin sections were obtained by covering the trimmed block with glue (Pattex®, Henkel, Germany, diluted 3:1 with xylene; [91]). Sections were collected on glass slides, stained with toluidine blue ( $0.5 \%$ toluidine blue in a $1 \%$ aqueous solution of borax for $15-30$ s at $60^{\circ} \mathrm{C}$ ), rinsed with $\mathrm{H}_{2} \mathrm{O}$, fixed with $5 \%$ ammonium molybdate tetrahydrate $((\mathrm{NH} \otimes) \otimes \mathrm{Mo} \otimes \mathrm{O} \otimes \nabla \times 4 \mathrm{H} \otimes \mathrm{O})$ and mounted with Entellan mounting medium. Alternatively, sections were stained in a $0.1 \%$ solution of toluidine blue for approximately $25 \mathrm{~min}$; further processing was as described above. Pictures were taken with a DMLS light microscope, Leica, Wetzlar, Germany, equipped with a Progress Gryphax ${ }^{\circledR}$ CCD camera (Jenoptik, Jena, Germany) and Gryphax software.

\section{Immunohistochemistry}

For confocal laser scanning microscopy (cLSM), small animals were fixed in $4 \%$ paraformaldehyde in phosphate-buffered saline (PPS: $140 \mathrm{mM} \mathrm{NaCl}, 6.5 \mathrm{mM} \mathrm{KCl}, 2.5 \mathrm{mM} \mathrm{Na}_{2} \mathrm{HPO}_{4}, 1.5 \mathrm{mM} \mathrm{KH}_{2} \mathrm{PO}_{4}, 12 \%$ sucrose, $\mathrm{pH} 7.4$ ) at $4^{\circ} \mathrm{C}$ and $2.5 \mathrm{~h}$. After fixation, specimens were rinsed in PBS and stored in the same buffer containing a few crystals of $\mathrm{NaN}_{3}$ to avoid growth of bacteria and fungi. Either whole mounts or dissected specimens were used. Prior to immunolabeling, specimens were incubated with PBT (9mI PBS $+1 \mathrm{ml} 1 \%$ Triton X-100) containing $6 \%$ BSA (bovine serum albumin) for $1 \mathrm{~h}$ and finally incubated with the primary antibody for $2-4 \mathrm{~d}$ at $4{ }^{\circ} \mathrm{C}$. Primary antibody was mouse anti-acetylated a-tubulin (monoclonal, clone 6-11-B-1; Sigma-Aldrich, Heidelberg, Germany, dilution 1:1000 in PBT). Following several washes (3x in PBT, 20min each), the secondary antibody was applied for $2-3 \mathrm{~d}$ at $4^{\circ} \mathrm{C}$ (goat anti-mouse, Cy2 conjugated, Dianova, Hamburg, Germany, dilution 1:200). After being rinsed three times for 10min in PBS, specimens were mounted in Fluoromount (Southern Biotech, Birmingham, USA). Observations were made with a Zeiss Pascal 5 confocal laser scanning microscope (Zeiss, Jena, Germany). Z-stacks are displayed as maximum projections if not stated otherwise.

\section{Analysis and 3D reconstruction}

All images were further processed using Photoshop ${ }^{\circledR}$ to adjust brightness, contrast, and size, and Illustrator ${ }^{\circledR}$ for assembling and labeling the plates. 3-D reconstructions were made from a series of semithin sections comprising approximately 400 sections. Micrographs were taken in intervals of $5 \mu \mathrm{m}$ and blood vessels, coelomic cavities, other tissues were segmented with ImageJ/FIJI [92,93] using the TrakEM2 Plugin [94]. After alignment of the sections, the 3-D model was calculated with the 3DViewer Plugin [95].

\section{Declarations}

\section{Acknowledgments}

We are grateful to the head of our department, Prof Dr. A. Paululat, Osnabrueck, for various kinds of support. Dr. Larisse Faroni-Perez, Santa Catarina, Brazil, collected, fixed and provided specimens from reefs at Mont St. Michel Bay (Normandy, France). Thanks are also due to K. Etzold and W. Mangerich, 
Osnabrueck, for various kinds of technical assistance, particularly for introducing CM and TA to electron microscopy techniques.

\section{Funding}

No funding was received for this research.

\section{Availability of data and materials}

The material of Sabellaria alveolata (embedded blocks, semi-thin sections, and ultrathin sections) are stored at the Department of Zoology and Developmental Biology at the University of Osnabrück. All images taken are stored in the database Omero at the University of Osnabrück.

\section{Authors' contributions}

GP conceived the study. GP and CM collected, fixed, and embedded the material used. CM mainly concentrated on the opercular papillae, tentacular filaments, and palps and TA on the branchiae. All authors analyzed the data. GP took the lead in writing the MS; all authors contributed to writing and discussing the manuscript. All authors approved the final manuscript.

\section{Ethical approval and consent to participate}

We neither used endangered species nor were the investigated animals collected in protected areas. All applicable international, national, and/or institutional guidelines for the care and use of animals were followed.

\section{Consent for publication}

Not applicable

\section{Conflict of interest}

The authors declare that they have no conflict of interest.

\section{References}

1. Capa M, Hutchings P, Peart R. Systematic revision of Sabellariidae (Polychaeta) and their relationship with other polychaetes using morphological and DNA sequence data. Zool J Linn Soc. 2012;164:245-84.

2. Capa M, Faroni-Perez L, Hutchings P. Sabellariidae from Lizard Island, Great Barrier Reef, including a new species of Lygdamis and notes on external morphology of the median organ. Zootaxa. 2015;4019:184-206.

3. Capa M, Hutchings P. Sabellariidae In: Purschke G, Böggemann M, Westheide W, editors. Handbook of Zoology. Annelida. Vol 2 Pleistoannelida Sedentaria II. Berlin: DeGruyter; 2019. pp. 144-63. 
4. Rouse GW, Pleijel F. Polychaetes. Oxford: Oxford University Press; 2001. 354 pp.

5. Faroni-Perez L, Helm C, Burghardt I, Hutchings P, Capa M. Anterior sensory organs in Sabellariidae (Annelida). Inv Biol. 2016;13:423-47.

6. Meyer C, FaroniPerez L, Purschke G. Anterior sense organs in Sabellaria alveolata (Annelida, Sedentaria, Spionida) with special reference to ultrastructure of photoreceptor elements presumably involved in shadow reflex. Zoomorphology. 2019;138:39-54.

7. Kirtley DW. A review and taxonomic revision of the family Sabellariidae Johnston, 1865 (Annelida; Polychaeta) (series 1). Los Angeles: Sabecon Press Science; 1994.

8. Lechapt JP, Kirtley DW. Bathysabellaria spinifera (Polychaeta, Sabellariidae), a new species from deepwater off New Caledonia, southwest Pacific Ocean. Proc Biol Soc Wash. 1996;109:560-74.

9. Helm C, Bok MJ, Hutchings P, Kupriyanova E, Capa M. Developmental studies provide new insights into the evolution of sense organs in Sabellariidae (Annelida). BMC Evol Biol. 2018;18:149. https://doi.org/10.1186/s12862-018-1263-5.

10. Eckelbarger KJ. Metamorphosis and settlement in the Sabellariidae. Sabellariidae. In: Chia FS, Rice ME, editors. Settlement and metamorphosis of marine invertebrate larvae. New York: Elsevier Biomedial; 1978. pp. 145-64.

11. Eckelbarger KJ, Chia FS. Morphogenesis of larval cuticle in the polychaete Phragmatopoma lapidosa. A correlated scanning and transmission electron microscopic study from egg envelope formation to larval metamorphosis. Cell Tiss Res. 1978;186:187-201.

12. Eckelbarger KJ. Ultrastructural evidence for both autosynthetic and heterosynthetic yolk formation in the oocytes of an annelid (Phragmatopoma lapidosa: Polychaeta). Tiss Cell. 1979;11:425-43.

13. Eckelbarger KJ. Ultrastructure of spermatogensis in the reef-building polychaete Phragmatopoma lapidosa (Sabellariidae) with special reference to acrosome morphogenesis. J Ultrastruct Res. 1984;89:146-64.

14. Riisgård HU, Nielsen C: Feeding mechanism of the polychaete Sabellaria alveolata revisited: comment on Dubois et al. (2005). Mar Ecol Progr Ser 2006, 328: 295-305.

15. Amieva MR, Reed CG. Functional morphology of the larval tentacles of Phragmatopoma californica (Polychaeta: Sabellaridae): composite larval and adult organs of multifunctional significance. Mar Biol. 1987;95:243-58.

16. Amieva MR, Reed CG, Pawlik JR. Ultrastructure and behaviour of the larva of Phragmatopoma californica (Polychaeta: Sabellariidae): identification of sensory organs potentially involved in substrate selection. Mar Biol. 1987;95:259-66.

17. Meyer E. Studien über den Körperbau der Anneliden. Mitt zool Stat Neapel 1887, 7: 592-741.

18. Meyer E. Studien über den Körperbau der Anneliden. IV. Die Körperform der Serpulaceen und Hermellen. Mitt zool Stat Neapel 1888, 8: 462-662.

19. Orrhage L. On the structure and evolution of the anterior end of the Sabellariidae (Polychaeta, Sedentaria). With some remarks on the general organisation of the polychaete brain. Zool Jb Anat. 
1978;100:343-74.

20. Gardiner SL: Respiratory and feeding appendages. In: Westheide W, Hermans CO, editors. The Ultrastructure of Polychaeta. Microfauna Marina 1988, 4: 37-43.

21. Belova PA, Zhadan AE. Comparative morphology and ultrastructure of the respiratory system in four species of the Opheliidae family. Biol Bull. 2014;41:752-72.

22. Purschke G, Hugenschütt M, Ohlmeyer L, Meyer H, Weihrauch D. Structural analysis of the branchiae and dorsal cirri in Eurythoe complanata (Annelida, Amphinomida) Zoomorphology 2017, 136: 1-18.

23. Mendendez A, Arias JL, Tolivia D, Alvarez-Uria M. Ultrastructure of gill epithelial cells of Diopatra neapolitana (Annelida, Polychaeta). Zoomorphology. 1984;104:304-9.

24. Thiel D, Hugenschuett M, Meyer H, Paululat A, Quijada-Rodriguez AR, Purschke G, Weihrauch D. Ammonia excretion in the marine polychaete Eurythoe complanata (Annelida). Jexp Biol. 2017;220:425-36. (DOI: 10.1242/jeb.145615).

25. Hausen $\mathrm{H}$ : Comparative structure of the epidermis in polychaetes (Annelida). In: Bartolomaeus $\mathrm{T}$, Purschke G, editors. Morphology, molecules, evolution and phylogeny in Polychaeta and related taxa. Hydrobiologia 2005, 535/536: 24-35.

26. Storch V: Integument. In: Westheide W, Hermans CO, editors. The Ultrastructure of Polychaeta. Microfauna Marina 1988, 4: 13-36.

27. Worsaae K, Rouse GW. Is Diurodrilus an annelid? J Morphol. 2008;169:1426-55.

28. Purschke G: Pharynx. In: Westheide W, Hermans CO, editors. The Ultrastructure of Polychaeta. Microfauna Marina 1988, 4: 177-197.

29. Purschke G, Tzetlin AB. Dorsolateral ciliary folds in the polychaete foregut: Structure, prevalence and phylogenetic significance. Acta Zool (Stockh). 1996;77:33-49.

30. Kristensen RM, Niilonen T. Structural studies on Diurodrilus Remane (Diurodrilidae fam.n.) with description of Diurodrilus westheidei sp.n. from the Arctic interstitial meiobenthos, W. Greenland Zool Scr. 1982;11:1-12.

31. Purschke G, Bleidorn C, Struck T. Systematics, evolution and phylogeny of Annelida - a morphological perspective. Mem Mus Victoria. 2014;71:247-69.

32. Weigert A, Helm C, Meyer M, Nickel B, Arendt D, Hausdorf B, Santos SR, Halanych KM, Purschke G, Bleidorn C, Struck TH. Illuminating the base of the annelid tree using transcriptomics. Mol Biol Evol. 2014;31:1391-401.

33. Struck TH: Phylogeny. In: Purschke G, Böggemann M, Westheide W, editors. Handbook of Zoology Annelida Vol. 1: Annelida, basal groups and Pleistoannelida, Sedentaria I. Berlin, De Gruyter 2019: $37-68$.

34. Kristensen RM, Nørrevang A. Description of Psammodrilus aedificator sp.n. (Polychaeta), with notes on the Arctic interstitial fauna of Disko Island. W. Greenland Zool Scr. 1982;11:265-79.

35. Hausen H: Untersuchungen zur Phylogenie „spiomorpher“ Polychaeten (Annelida). PhD Thesis, Logos, Berlin, 2001. 
36. Purschke G, Hausen H. Lateral organs in sedentary polychaetes (Annelida) - Ultrastructure and phylogenetic significance of an insufficiently known sense organ. Acta Zool (Stockh). 2007;88:2339.

37. Jouin C, Toulmond A. The ultrastructure of the gill of the lugworm Arenicola marina (L.) (Annelida, Polychaeta). Acta Zool (Stockh). 1989;70:121-9.

38. Jouin C, Gaill F. Gills of hydrothermal vent annelids: structure, ultrastructure and functional implications in two alvinellid species. Progr Oceanol. 1990;24:59-69.

39. Welsch U, Storch V, Richards KS: Epidermal cells. In: Bereiter-Hahn J, Matoltsy AG, Richards KS, editors. Biology of the integument. Berlin, Heidelberg, New York, Tokyo, Springer 1984: 269-296.

40. Storch V, Welsch U. Über die Feinstruktur der Polychaeten-Epidermis. Z Morph Ökol Tiere. 1970;66:310-22.

41. Purschke G: Sense organs in polychaetes (Annelida). ). In: Bartolomaeus T, Purschke G, editors. Morphology, molecules, evolution and phylogeny in Polychaeta and related taxa. Hydrobiologia 2005, 535/536: 53-78.

42. Storch V, Schlötzer-Schrehardt U: Sensory structures. In: Westheide W, Hermans CO, editors. The Ultrastructure of Polychaeta. Microfauna Marina 1988, 4: 121-133.

43. Purschke G. Annelida: Basal groups and Pleistoannelida. In: Schmidt-Rhaesa A, Harzsch S, Purschke G, editors. Structure and Evolution of Invertebrate Nervous Systems. Oxford: Oxford University Press; 2016. pp. 254-312.

44. Shigeno S, Ogura A, Mori T, Toyohara H, Yoshida T, Tsuchida S, Fujikura K. Sensing deep extreme environments: the receptor cell types, brain centers, and multi-layer neural packaging of hydrothermal vent endemic worms. Front Zool. 2014;11:82.

45. Verger-Bocquet M. Polychaeta: Sensory structures. In: Harrison FW, Gardiner SL, editors. Microscopic Anatomy of Invertebrates. Vol 7 Annelida. New York: Chichester; Wiley-Liss 1992. pp. 181-96.

46. Schmidt-Rhaesa A. The Evolution of Organ Systems. New York: Oxford University Press; 2007. 385 pp.

47. Lawry JV Jr: Structure and function of the parapodial cirri of the polynoid polychaete, Harmothoe. Z Zellforsch mikrosk Anat 1967, 82: 345-461.

48. Dorsett DA, Hyde R. The fine structure of the compound sense organs on the cirri of Nereis diversicolor. Z Zellforsch mikrosk Anat 1969, 97: 512-527.

49. Boilly-Marer Y. Étude ultrastructurale des cirres parapodiaux de Nereidiens atoques (Annélides, Polychètes). Z Zellforsch mikrosk Anat. 1972;131:309-27.

50. Schlawny A, Grünig C, Pfannenstiel HD. Sensory and secretory cells of Ophryotrocha puerilis. (Polychaeta) Zoomorphology. 1991;110:209-15.

51. Purschke G. Structure of the prostomial appendages and the central nervous system in the Protodrilida (Polychaeta). Zoomorphology. 1993;113:1-20. 
52. Eckelbarger KJ. Developmental studies of the post-settling stages of Sabellaria vulgaris (Polychaeta: Sabellariidae). Mar Biol. 1975;30:137-49.

53. Ebling FJ. Formation and nature of the opercular chaetae of Sabellaria alveolata. Quart J microsc Sci. 1944;85:153-76.

54. Eckelbarger KJ. Larval Development of Sabellaria floridensis from Florida and Phragmatopoma californica from Southern California (Polychaeta: Sabellariidae), with a key to the sabellariid larvae of Florida and a review of development in the family. Bull Mar Sci. 1977;27:241-55.

55. Dubois S, Barillé L, Cognie B, Beninger PG. Particle capture and processing mechanisms in Sabellaria alveolata (Polychaeta: Sabellariidae). Mar Ecol Progr Ser. 2005;301:159-71.

56. Horridge GA. Proprioceptors, bristle receptors, efferent sensory impulses, neurofibrils and number of axons in the parapodial nerve of the polychaete Harmothoe. Proc Roy Soc Lond B Biol Sci. 1963;157:199-222.

57. Dales RP. The development and structure of the anterior region of the body in the Sabellariidae, with special reference to Phragmatopoma californica. Quart J microsc Sci. 1952;93:435-52.

58. Dubois S, Barille L, Cognie B, Beninger B. P. Feeding mechanism of the polychaete Sabellaria alveolata revisited: reply to Riisgård \& Nielsen (2006). Mar Ecol Progr Ser. 2006;328:307-11.

59. Johansson KE. Beiträge zur Kenntnis der Polychaeten-Familien Hermellidae, Sabellidae und Serpulidae. Zool Bidr Uppsala. 1927;11:1-184.

60. Fransen ME: Coelomic and vascular systems. In: Westheide W, Hermans CO, editors. The Ultrastructure of Polychaeta. Microfauna Marina 1988, 4: 199-213.

61. Bartolomaeus T. On the ultrastructure of the coelomic lining in the Annelida, Sipuncula and Echiura. Microfauna Mar. 1994;9:171-220.

62. Rieger RM, Purschke G: The coelom and the origin of the annelid body plan. In: Bartolomaeus T, Purschke G, editors. Morphology, molecules, evolution and phylogeny in Polychaeta and related taxa. Hydrobiologia 2005, 535/536: 127-137.

63. Smith PR, Chia FS. Larval development and metamorphosis of Sabellaria cementarium Moore, 1906 (Polychaeta, Sabellariidae). Can J Zool. 1985;63:1037-49.

64. Orrhage L. Anatomische und morphologische Studien über die Polychaetenfamilien Spionidae, Disomidae und Poecilochaetidae. Zool Bidr Uppsala. 1964;36:335-405.

65. Orrhage L. Über die Anatomie, Histologie und Verwandtschaft der Apistobranchidae (Polychaeta, Sedentaria) nebst Bemerkungen über die systematische Stellung der Archianneliden. Z Morph Ökol Tiere. 1974;79:1-45.

66. Martin GG. Ciliary gliding in lower invertebrates. Zoomorphologie. 1978;91:249-61.

67. Pawlik JR. Chemical induction of larval settlement and metamorphosis in the reef-building tube worm Phragmatopoma californica (Sabellariidae: Polychaeta). Mar Biol. 1986;91:59-68.

68. Pawlik JR, Faulkner DJ. Specific free fatty acids induce larval settlement and metamorphosis of the reef-building tube worm Phragmatopoma californica (Fewkes). J exp mar Biol Ecol. 1986;102:301- 
10a.

69. Rouse GW. Polychaeta, including Pogonophora and Myzostomida. In: Adiyodi KG, Adiyodi RG, editors. Reproductive Biology of Invertebrates. Vol IX Part B Progress in male gamete ultrastructure and phylogeny. Calcutta: New Delhi; 1999. pp. 43-124.

70. Brinkhurst RO, Jamieson BGM. Aquatic oligochaeta of the world. Edinburgh: Oliver \& Boyd; 1971.

71. Jamieson BGM. Oligochaeta. In: Harrison FW, Gardiner SL, editors. Microscopic anatomy of invertebrates. New York: Wiley-Liss; 1992. pp. 217-33.

72. Gardiner SL. Polychaeta: General organization, integument, musculature, coelom and vascular system. In: Harrison FW, Gardiner SL, editors. Microscopic Anatomy of Invertebrates. Vol 7 Annelida. Chichester: Wiley-Liss; 1992. pp. 19-52.

73. Andersen AC, Jolivet S, Claudinot S, Lallier FH. Biometry of the branchial plume in the hydrothermal vent tubeworm Riftia pachyptila (Vestimentifera; Annelida). Can J Zool. 2002;80:320-32.

74. Southward EC, Schulze A, Gardiner SL: Pogonophora (Annelida): form and function. In:

Bartolomaeus T, Purschke G, editors. Morphology, molecules, evolution and phylogeny in Polychaeta and related taxa. Hydrobiologia 2005, 535/536: 227-251.

75. Huusgaard RS, Vismann B, Kühl M, Macnaugton M, Colmander V, Rouse GW, Glover AG, Dahlgren T, Worsaae K. The potent respiratory system of Osedax mucofloris (Siboglinidae, Annelida) - a prerequisite for the origin of bone-eating. Osedax? PlosOne. 2012;7:e35975.

76. Bartolomaeus T. On the ultrastructure of the cuticle, the epidermis and the gills of Sternaspis scutata (Annelida). Microfauna Mar. 1992;7:237-52.

77. Hourdez S, Jouin-Toulmond C. Functional anatomy of the respiratory system of Branchipolynoe species (Polychaeta, Polynoidae), commensal with Bathymodiolus species (Bivalvia, Mytilidae) from deep-sea hydrothermal vents. Zoomorphology. 1998;118:225-33.

78. Hourdez S, Frederick LA, Schernecke A, Fisher CR. Functional respiratory anatomy of a deep-sea orbiniid polychaete from the Brine Pool NR-1 in the Gulf of Mexico. Inv Biol. 2001;120:29-40.

79. Jouin-Toulmond C, Hourdez S. Morphology, ultrastructure and functional anatomy of the branchial organ of Terebellides stroemii (Polychaeta: Trichobranchidae) and remarks on the systematic position of the genus Terebellides. Cah Biol Mar. 2006;47:287-99.

80. Stekolshchikov MG. Struvture an devolution of respiratory organs in polychaetes. Uch Zap Kazan Gos Univ. 1954;114:23-53. [in Russian].

81. Wells RMG, Jarvis PJ, Shumway SE. Oxygen uptake, the circulatory system, and haemoglobin function in the intertidal polychaete Terebella haplochaeta (Ehlers). J exp mar Biol Ecol. 1980;46:255-77.

82. Storch V, Alberti G. Ultrastructural observations on the gills of polychaetes. Helgol wiss Meeresunters. 1978;31:169-79.

83. Spies RB. Structure and function of the head in flabelligerid polychaetes. J Morphol. 1975;147:187208. 
84. Storch V, Gaill F. Ultrastructural observations on feeding appendages and gills of Alvinella pompejana (Annelida, Polychaeta). Helgol Meeresunters. 1986;40:309-19.

85. Tzetlin AB, Zhadan AE, Vortsepneva EV. Innervation of unpaired branchial appendages in the annelids Terebellides cf. stroemii (Trichobranchidae) and Cossura pygodactylata (Cossuridae). Biol Bull. 2018;45:43-52.

86. Ruppert EE, Carle KJ. Morphology of metazoan circulatory systems. Zoomorphology. 1983;103:193208.

87. Westheide W. The direction of evolution within the Polychaeta. J Nat Hist. 1997;31:1-15.

88. Hartenstein V, Mandal L. The blood/vascular system in a phylogenetic perspective. Bioessays. 2006;28:1203-10.

89. Dhainaut A, Porchet-Henneré E: Haemocytes and coelomocytes. In: Westheide W, Hermans CO, editors. The Ultrastructure of Polychaeta. Microfauna Marina 1988, 4: 215-230.

90. Ermak TH, Eakin RM. Fine structure of the cerebral and pygidial ocelli in Chone ecaudata (Polychaeta: Sabellidae). J Ultrastruct Res. 1976;54:243-60.

91. Blumer MJF, Gahleitner P, Narzt T, Handl C, Ruthensteiner B. Ribbons of semithin sections an advanced method with a new type of diamond knife. J Neurosci Meth. 2002;120:11-6.

92. Schneider CA, Rasband WS, Eliceiri KW. NIH image to ImageJ: 25 years of image analysis. Nat Methods. 2012;9:671-5.

93. Schindelin J, Arganda-Carreras I, Frise E, Kaynig V, Longair M, Pietzsch T, Preibisch S, Rueden C, Saalfeld S, Schmid B, Tinevez J-Y, White DJ, Hartenstein V, Eliceiri K, Tomancak P, Cardona A. Fiji: an open-source platform for biological-image analysis. Nat Methods. 2012;9:671-5.

94. Cardona A, Saalfeld S, Schindelin J, Arganda-Carreras I, Preibisch S, Longair M, Tomancak P, Hartenstein V, Douglas PR: TrakEM2 software for neuronal circuit reconstruction. PloS One 2012, /, e38011.

95. Schmid B, Schindelin J, Cardona A, Longair M, Heisenberg M. A high level 3d visualization API for Java and Image J. BMC informatics. 2010;11:1.

\section{Figures}




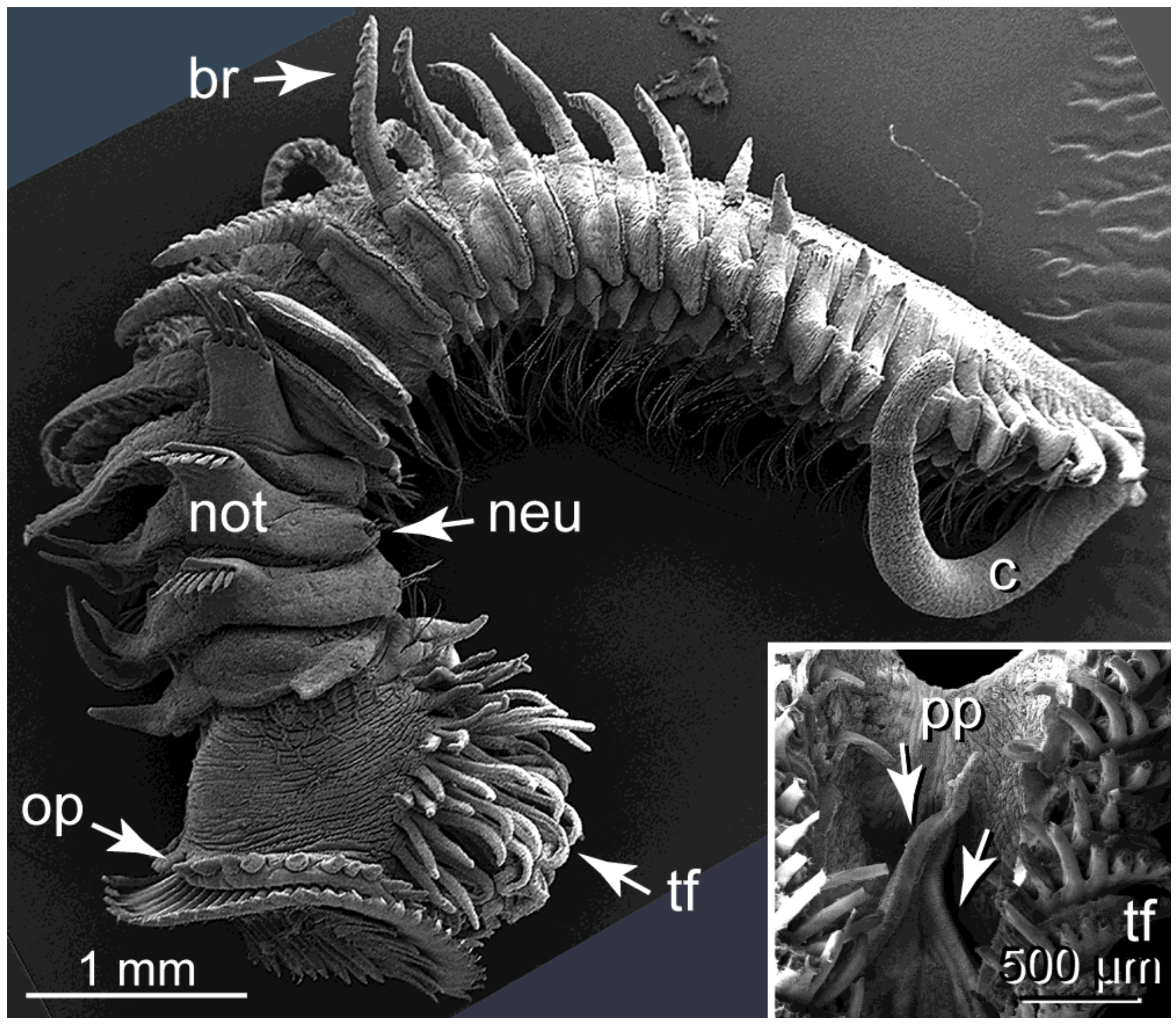

Figure 1

S. alveolata from Saint-Efflam, France. SEM images. Whole specimen in lateral view exhibiting diversity of body appendages. A ring of opercular papillae (op) is present directly underneath the opercular paleae. On the ventral side of the operculum, several tentacular filaments (tf) protrude from the body and surround the mouth. Posterior, three parathoracic segments with capillary chaetae-bearing notopodia (not) and abdominal paddle-shaped notopodia are present. Neuropodia (neu) with simple capillary chaetae. Branchiae (br) are present dorsally on each segment except for the first thorax segment. The posterior end forms the unsegmentated cauda (c). Inset: Ventral view of the opened operculum.

Tentacular filaments partly removed to show the two palps (pp) located inside the opercular cavity and protruding anteriorly. br branchia, c cauda, neu neuropodium, not notopodium, op operculum, pp palp, tf tentacular filament. 

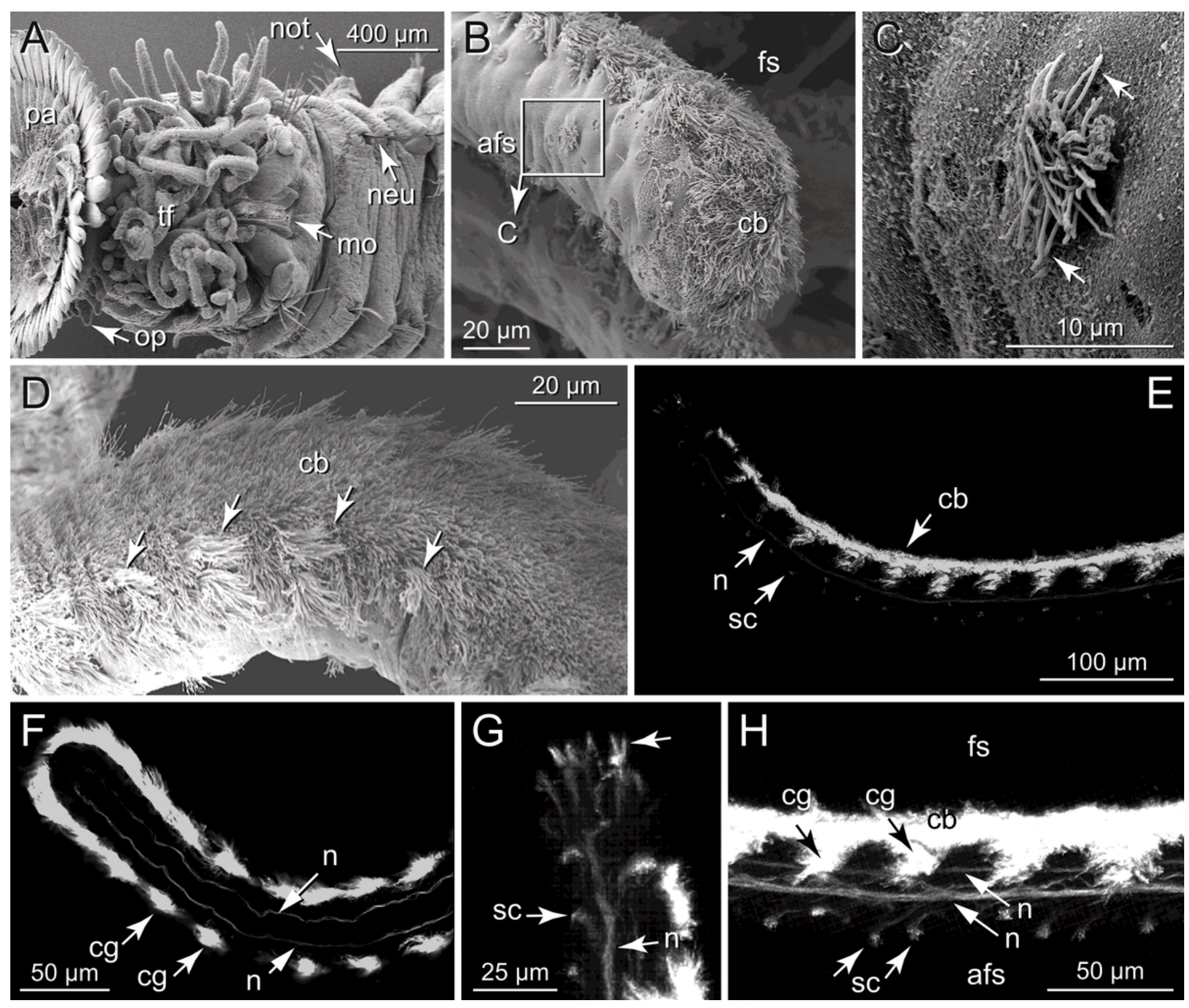

Figure 2

S. alveolata. Ultrastructure of opercular papillae. a, b: SEMs. c-h: Iongitudinal TEM sections. a: The opercular papillae (op) are located posteriorly on the operculum, underneath the opercular paleae (pa). They are arranged in a circle and surround the entire head region while protruding finger-like outwards. b: View on the tip of one opercular papilla showing several ciliary bundles (arrows). c: Gland cells (gc) with electron-lucent content open as pores in the cuticle and are connected to the neighboring cells via zonula adherens (za). d: Longitudinal section of a papilla with prominent epidermal layer surrounding the connective tissue (ct) extending from the opercular connective tissue. Several gland cells (gc) can be found between epidermal supportive cells. On the lateral sides, some ciliated receptor cells are present (arrows). e: Basal ecm between epidermis and connective tissue (arrows). Longitudinal muscles (Im) face the space between the connective tissue and ecm. f: Additional bundles of cross-sectioned muscle fibers (mu) are present in the connective tissue (ct). g, h: Details of ciliated receptor cells and microvilli (mv) 
penetrating the cuticle (cu), groups of receptor cells comprise monociliary and multiciliary cells, cuticle devoid of collagen fibers, receptor cells are adjoined to each other and the following supportive cells via zonula adherentes (za), sensory cilia with basal plate (bp). bp basal plate, ct connective tissue, cu cuticle, gc gland cell, Im longitudinal muscle, mu musculature, mv microvilli, op opercular papillae, pa opercular paleae, za zonula adherens.
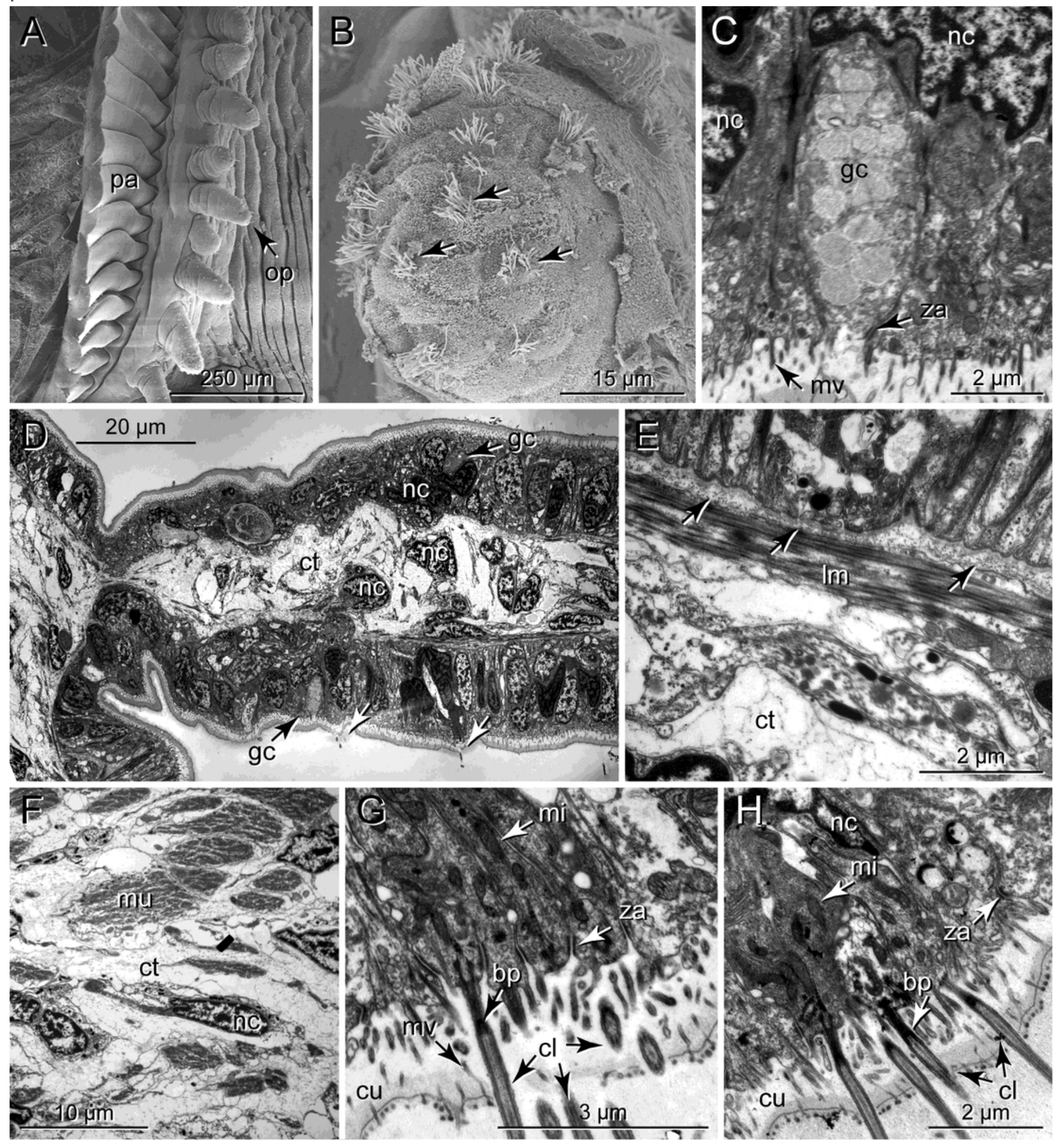

\section{Figure 3}


S. alveolata. Tentacular filaments. a-d: SEMs, e-f: selected slices of cLSM z-stacks. Anti-acetylated atubulin-like immuno-reactivity. a: Tentacular filaments (tf) located ventrally on the operculum, on the external side of the opercular lobes. b: Ventro-lateral view of a tentacular filament carrying a strong ciliary band ( $\mathrm{cb}$ ) on the frontal side ( $\mathrm{fs}$ ) and a few groups of cilia on the afrontal side (boxed). c: Detail of the ciliary group from b presumably belonging to receptor cells. $d$ : Each tentacular filament exhibits regularly arranged groups of longer cilia (arrows) located laterally in the strong frontal ciliary band (cb). e: Lateral view showing the strong ciliary band (cb) and ciliary groups. Sensory cilia (sc) are present on the afrontal side. $\mathrm{f}$ : View from the frontal side selected $\mathrm{z}$-stack projection to eliminate the strong signal of the ciliary band, making visible the two nerves ( $\mathrm{n}$ ) running along the afrontal side of the tentacular filament. g: Detail of the tip of the filament with groups of sensory cilia on the very top (arrow). The afrontally running nerves ( $n$ ) branch and the processes give rise to sensory cilia on the afrontal side. h: Enlargement of the middle part of a tentacular filament, lateral view. Each sensory ciliary bundle (sc) is connected via a single neurite to the ventrally running nerves. cb ciliary band, fs frontal side, $\mathrm{n}$ nerve, sc sensory cilia, $\mathrm{tf}$ tentacular filament.

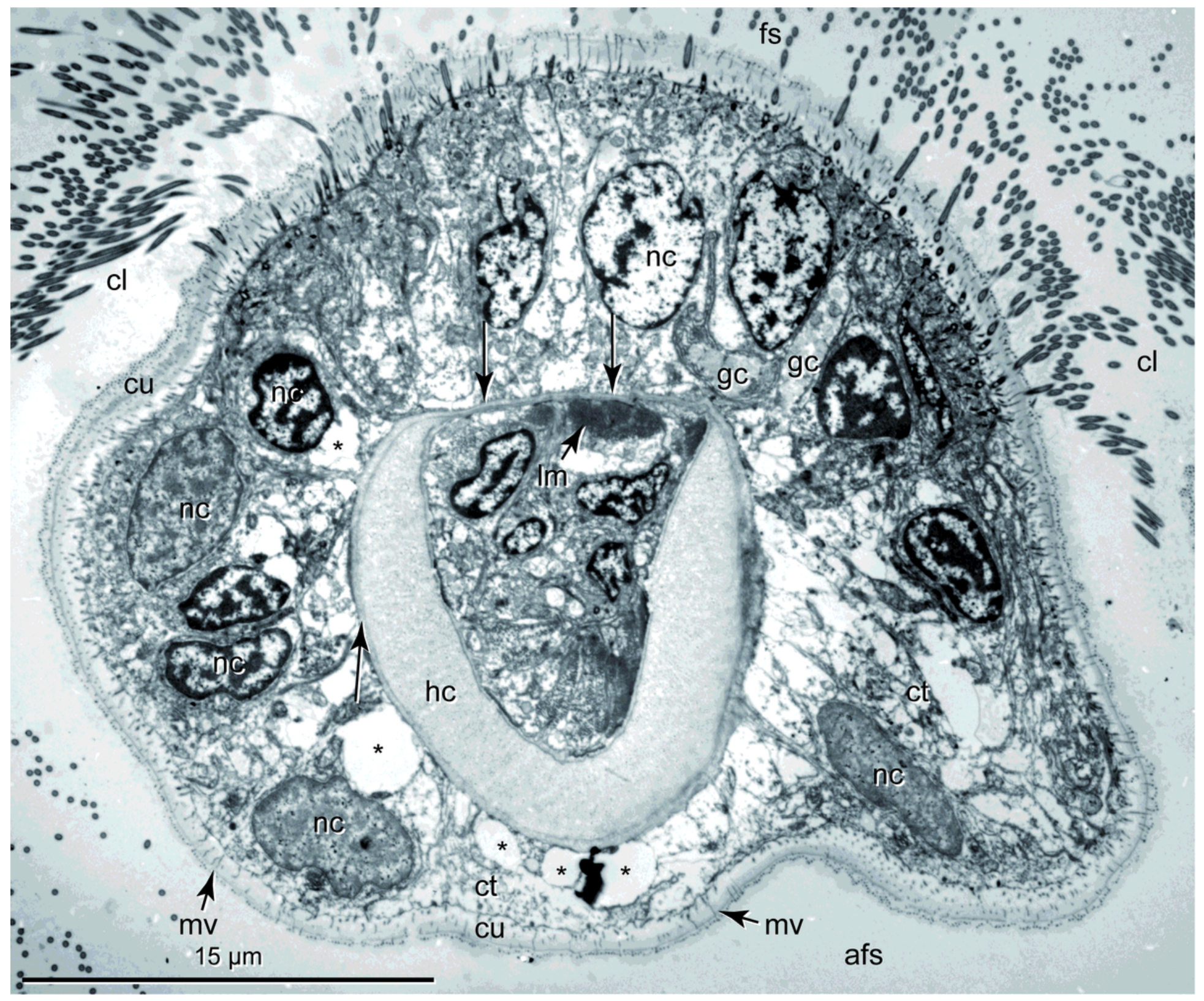




\section{Figure 4}

S. alveolata. Ultrastructure of tentacular filaments, TEM cross-section. Epithelium composed of supportive cells with prominent bundles of intermediate filaments, ciliated cells and gland cells. On the frontal side, numerous cilia (cl) penetrate the cuticle (cu). Inside the filament surrounded by the epidermal epithelium a prominent u-shaped, hyaline cartilage structure (hc) is present. It is surrounded by a prominent ecm, also connecting both ends of the cartilage structure together (arrows) and separating a central bundle of musculature primarily comprising longitudinal muscle fibers $(\mathrm{Im})$ attached circularly to the ecm and running from the base to the tip of the filament. Gland cells (gc) with electron-lucent material interspersed between epithelial cells on the frontal side ( $\mathrm{fs}$ ). cl cilia, cu cuticle, fs frontal side, gc gland cell, hc hyaline cartilage structure, Im longitudinal muscle. 


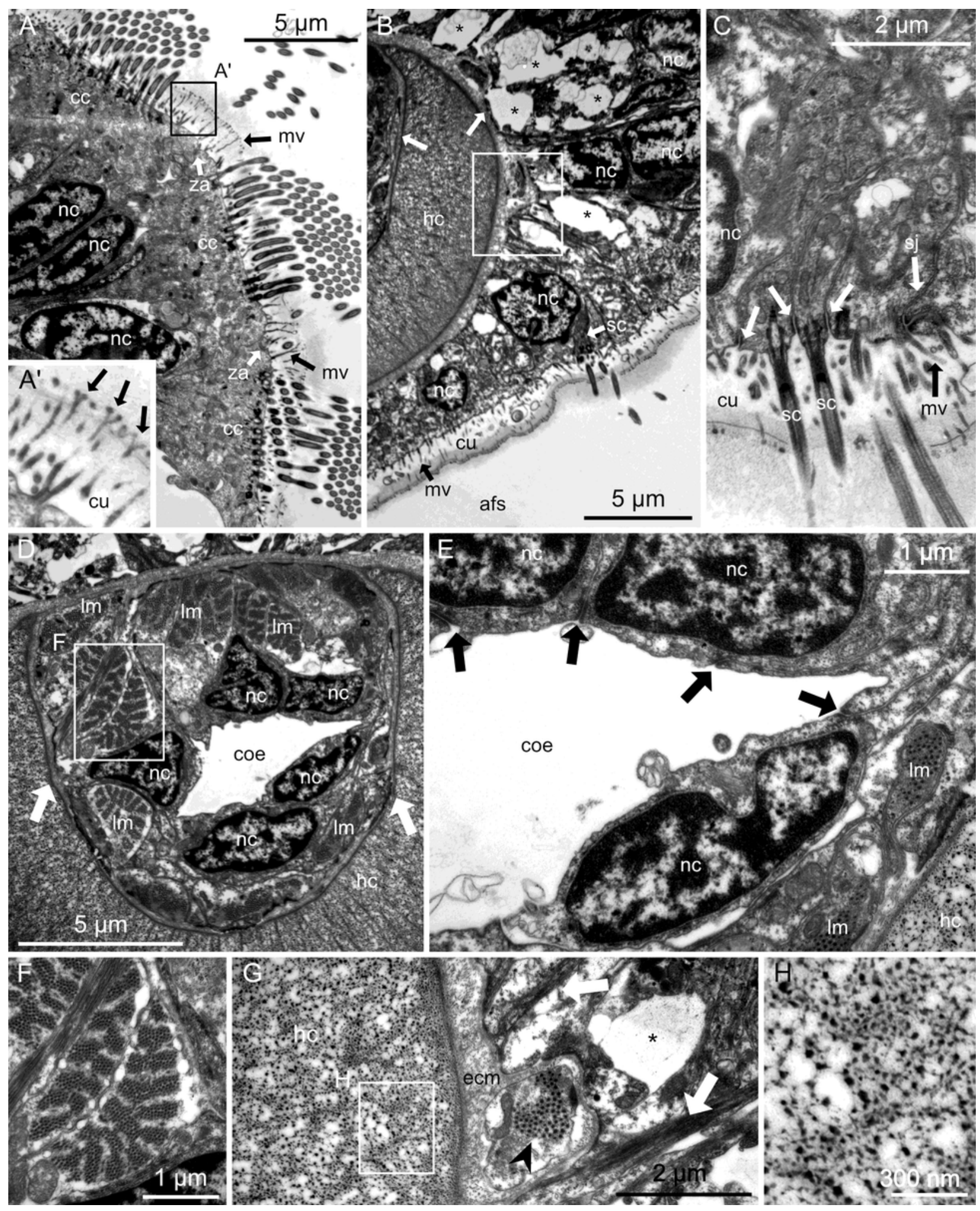

Figure 5

S. alveolata. Ultrastructure of tentacular filaments, TEM cross-sections. a: Three multiciliated cells (cc) located laterally on each side of the frontal ciliary band. Each group of cilia distinctly separated from its neighbor by the unciliated periphery of the cells. Cuticle (cu) devoid of collagen fibers, penetrated by microvilli (mv). Note distal branching of microvilli (mv) (boxed and inset a'). b: U-shaped hyaline cartilage structure surrounded by ecm and connected to intermediate filaments. Single groups of sensory cilia (sc) 
are located on the afrontal side of the filament. c: Detail of 3 receptor cells on the afrontal side, sensory cilia with basal body and short rootlet. Cells are adjoined to each other by zonula adherentes (arrows) and septate junctions (sj). d: Inner side of u-shaped cartilaginous (hyaline) structure with coelom (coe) supplied with a strand of musculature primarily comprising longitudinal and a few supplementary circular fibers. e: Detail of coelom (coe) within the tentacular filament with zonula adherentes (arrows). f: Detail of a longitudinal muscle of the inner epithelium. g: Enlargement of an outer section from b (boxed) showing u-shaped structure surrounded by ecm (ecm), in contact with intermediate filaments via hemidesmosomes (arrows). Note small longitudinal outer muscle fiber (arrowhead). Asterisks mark tissue free spaces between epidermal cells. h: Detail (boxed in g) of the material comprising the u-shaped hyaline cartilaginous structure. cc ciliated cell, coe coelom, cu cuticle, ecm ecm, mv microcilli, sc sensory cilia, sj septate junction.

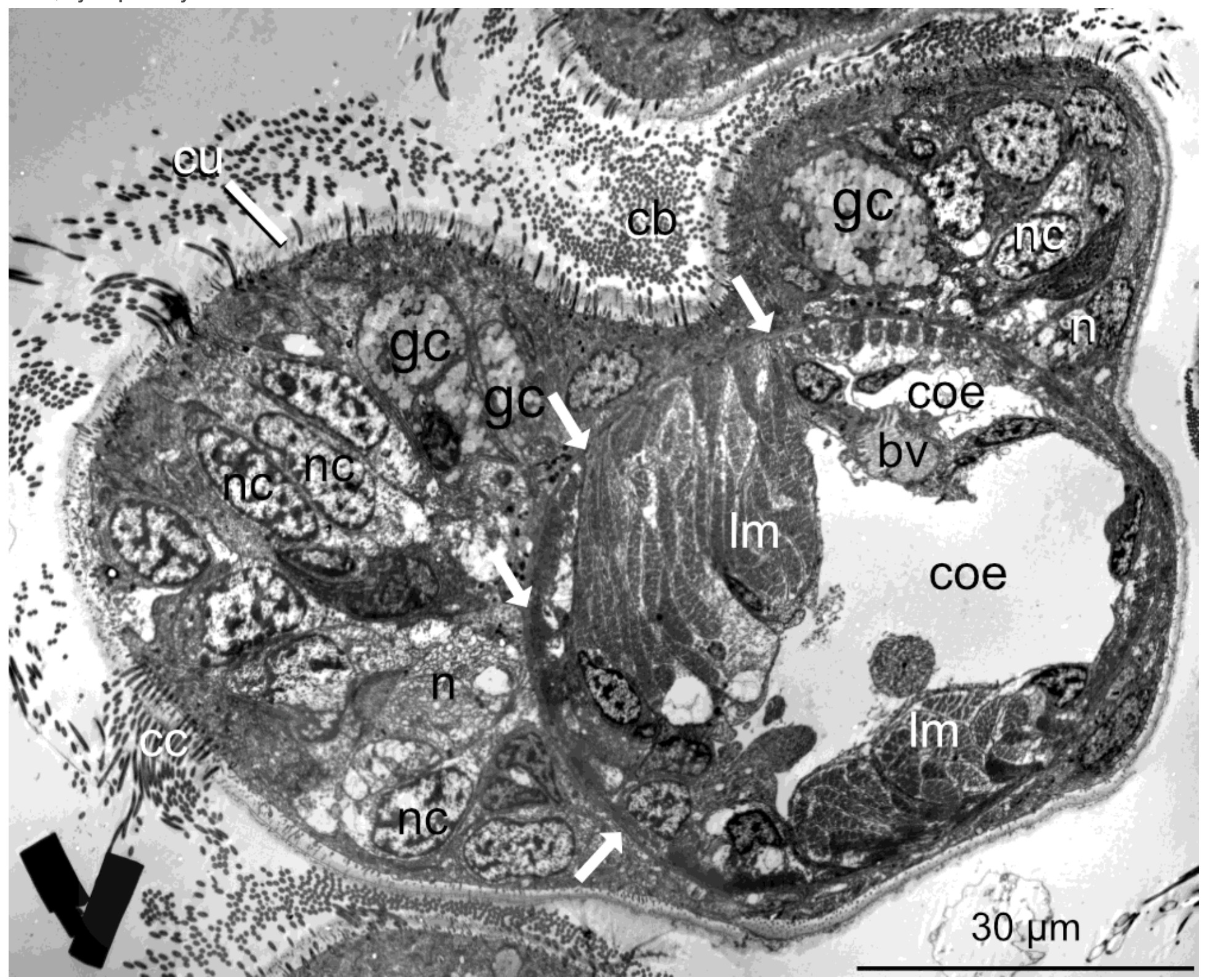

Figure 6 
S. alveolata. Palp. TEM cross-section. Palp with dense ciliation (cb) running from its base to the tip, laterally flanked by separated ciliated cells (cc). Gland cells (gc) with electron-lucent content are present in the epithelium, as well as two nerves (n). They run laterally along the longitudinal axis of the palp. The palp is supplied with two tubular coelomic cavities (coe), their peritoneum primarily comprises musculature compressing the lumen of the cavity. Musculature consists of an outer ring of circular musculature (arrows) followed by prominent longitudinal fibers (Im) A single blood vessel (bv) runs from the base to the tip of the palp where it ends blindly. It is formed within a strand of ecm connected to the circular ecm surrounding the mesodermal tissues and splitting the coelom into two parts. bv blood vessel, cb ciliary band, cc ciliated cell, coe coelom, cu cuticle, gc gland cell, Im longitudinal musculature, n nerve, nc nucleus.
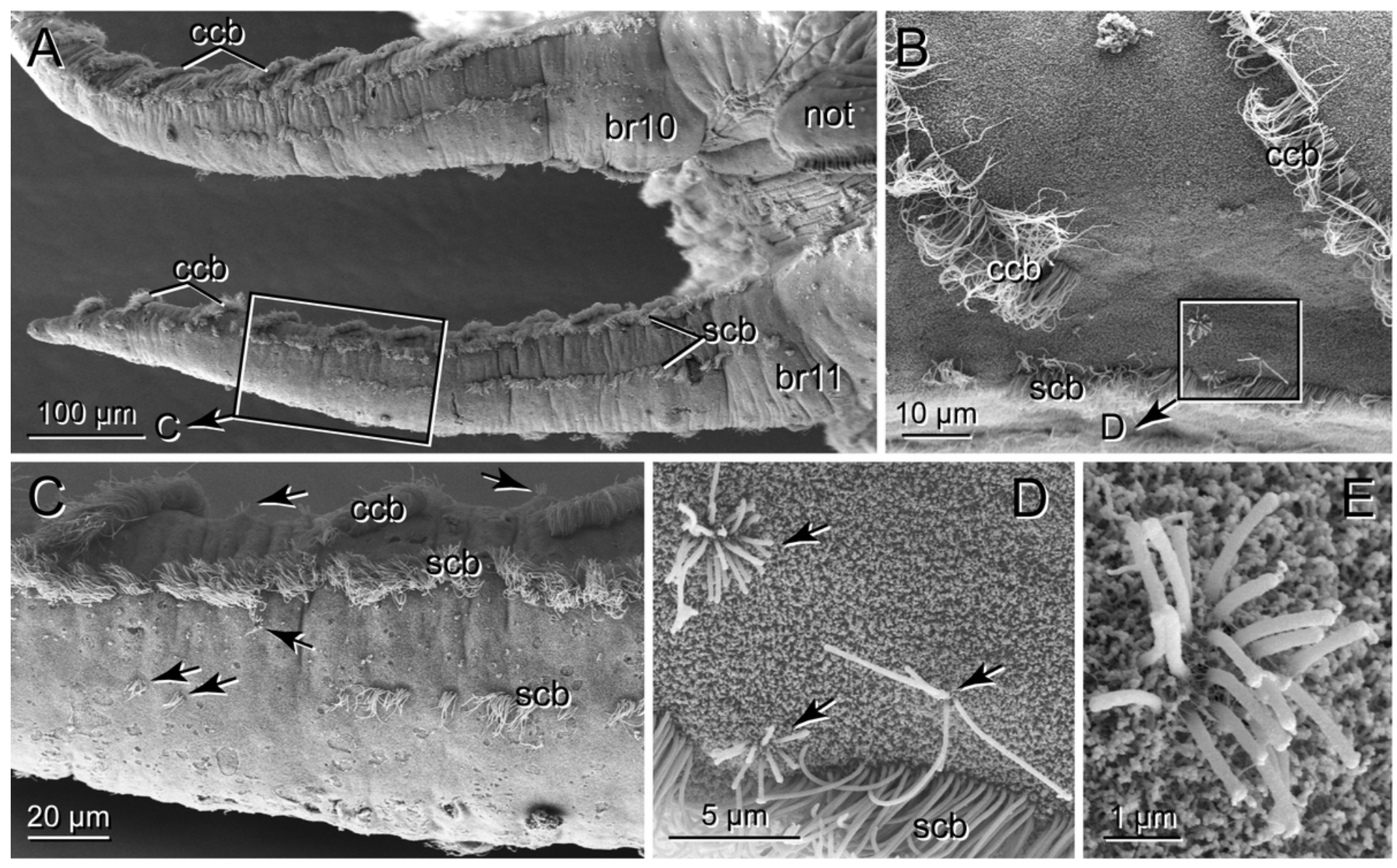

\section{Figure 7}

S. alveolata. Branchiae. a-e: SEM images. a: Two mid-body branchiae from abdomen (10th, 11th branchia; br10, br11). Each branchia with a specific pattern of cilia: two straight and somewhat discontinuous bands (scb) situated on the outer surface following the longitudinal axis, the anterior one giving rise to semicircular curved bands (ccb) facing the inner side of branchia. Boxed area shows enlarged region in c. b: View from inner side showing curved ciliary band and straight band with groups of receptor cell cilia (boxed and enlarged in d). c: End of outer straight ciliary band (scb), arrows point to various tufts of receptor cell cilia. $d$ : Enlargement of the three groups of sensory cell cilia from b; rough surface is represented by tips of epidermal microvilli. e: Single tuft of sensory cilia with epidermal 
microvilli at high magnification. br branchia, ccb curved ciliary band, scb straight ciliary band, not notopodium.

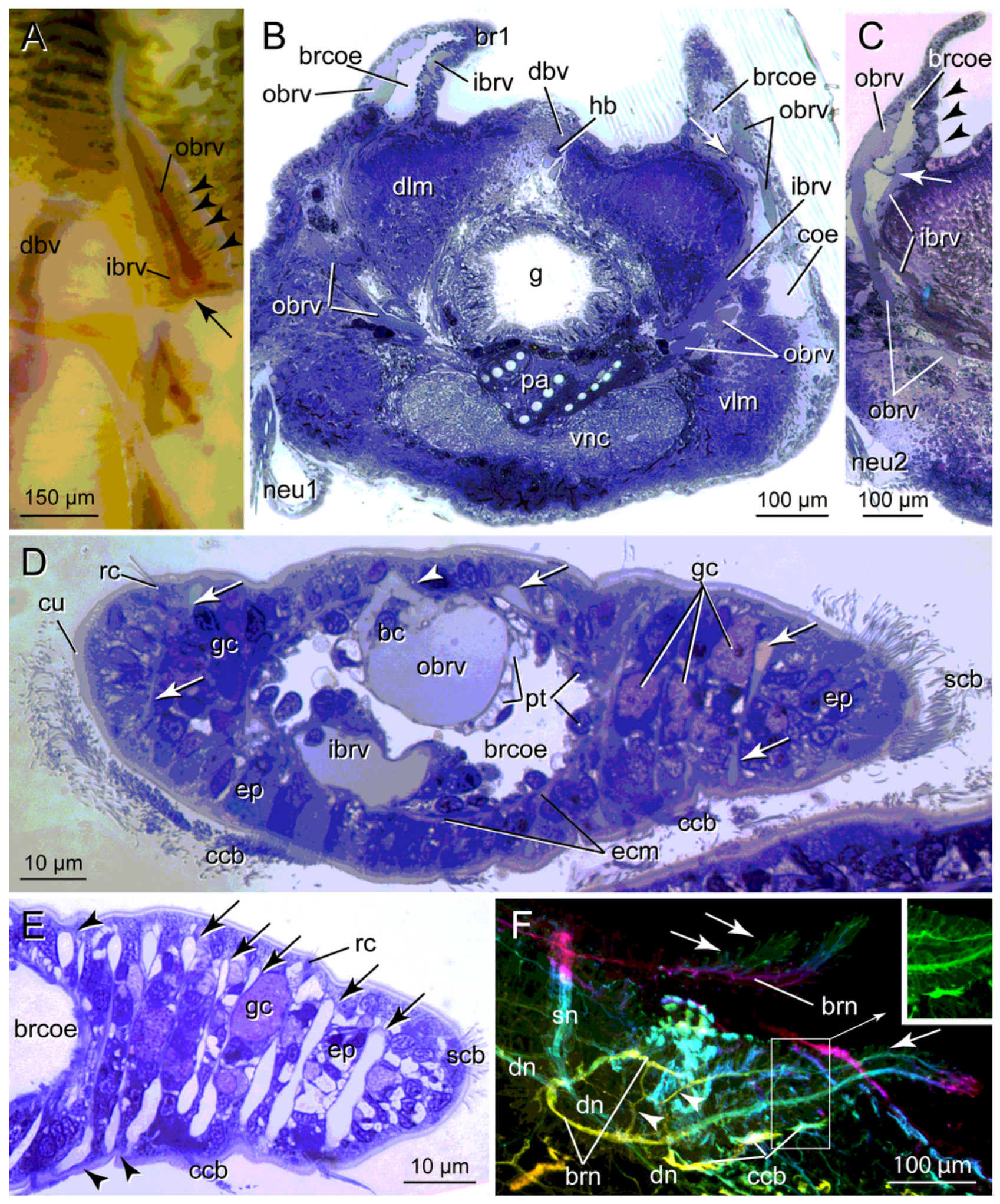

Figure 8

S. alveolata. Branchiae. a: Close-up of anterior end showing the 3 anterior-most right branchiae, the dorsal blood vessel (dbv), inner (ibrv) and outer branchial vessel (obrv); arrowheads point to transverse blood spaces giving the branchia a ladder-like appearance, arrow marks connecting vessel of ibrv with 
obrv. Specimen fixed with paraformaldehyde. b: Cross-section through thorax with 1st pair of branchiae; branchiae supplied with a coelomic space (brcoe) and two prominent blood vessels, outer and inner vessel (obrv, ibrv), which are interconnected at the base of branchiae (arrow) and extend deep into the body below the gut (g). c: Blood supply of 2 nd branchia, arrow points to vessel connecting the two main blood vessels (ibrv, obrv) and simultaneously separating the branchial coelom (brcoe) from the main body cavity. d: Somewhat oblique section through mid-body branchia; epidermis (ep) covered by cuticle (cu), comprises glandular cells (gc), receptor cells (rc) and ciliated cells forming the straight (scb) and curved ciliary bands (ccb); regularly arranged transverse blood vessels (arrows) situated deep in the epidermis and originating from the main vessels (arrowhead); branchial coelom surrounded by peritoneum (pt) and strong ECM (ecm), blood vessels are formed within ECM, note blood cell (bc) in outer blood vessel (obrv). e: Regularly arranged transverse vessels (arrows) between cell bodies of epidermal supportive (ep) and gland cells (gc); in the periphery blood spaces almost reach the epithelial surface (arrowheads). f: Innervation pattern of branchiae, anti-acetylated a-tubulin-immune-like reactivity, dorsolateral view; each branchia is innervated by two nerves (brn) having a common origin where the dorsal nerve (dn) meets the main segmental nerve (sn), the branchial nerves are irregularly interconnected (arrowheads) and give off numerous dendritic processes with sensory cilia giving the branchia a herringbone-like pattern (arrows and inset). bc blood cell (hemocyte), br branchia, brcoe branchial coelom, brn branchial nerve, ccb curved ciliary band, coe coelom, cu cuticle, dbv dorsal blood vessel, dlm dorsal longitudinal musculature, dn dorsal nerve, ecm extracellular matrix, ep epidermis, g gut, gc gland cell, hb heart body, ibrv inner branchial vessel, neu neuropodium, obrv outer branchial vessel, pa palea, pt peritoneum, rc receptor cell, scb straight ciliary band, sn segmental nerve, vlm ventral longitudinal muscle, vnc ventral nerve cord. a dissecting microscope, $b$-e LM, semi-thin sections stained with toluidine blue; $f$

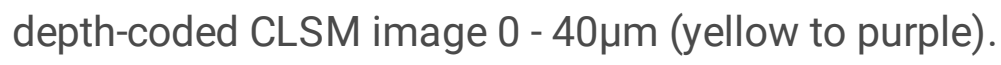




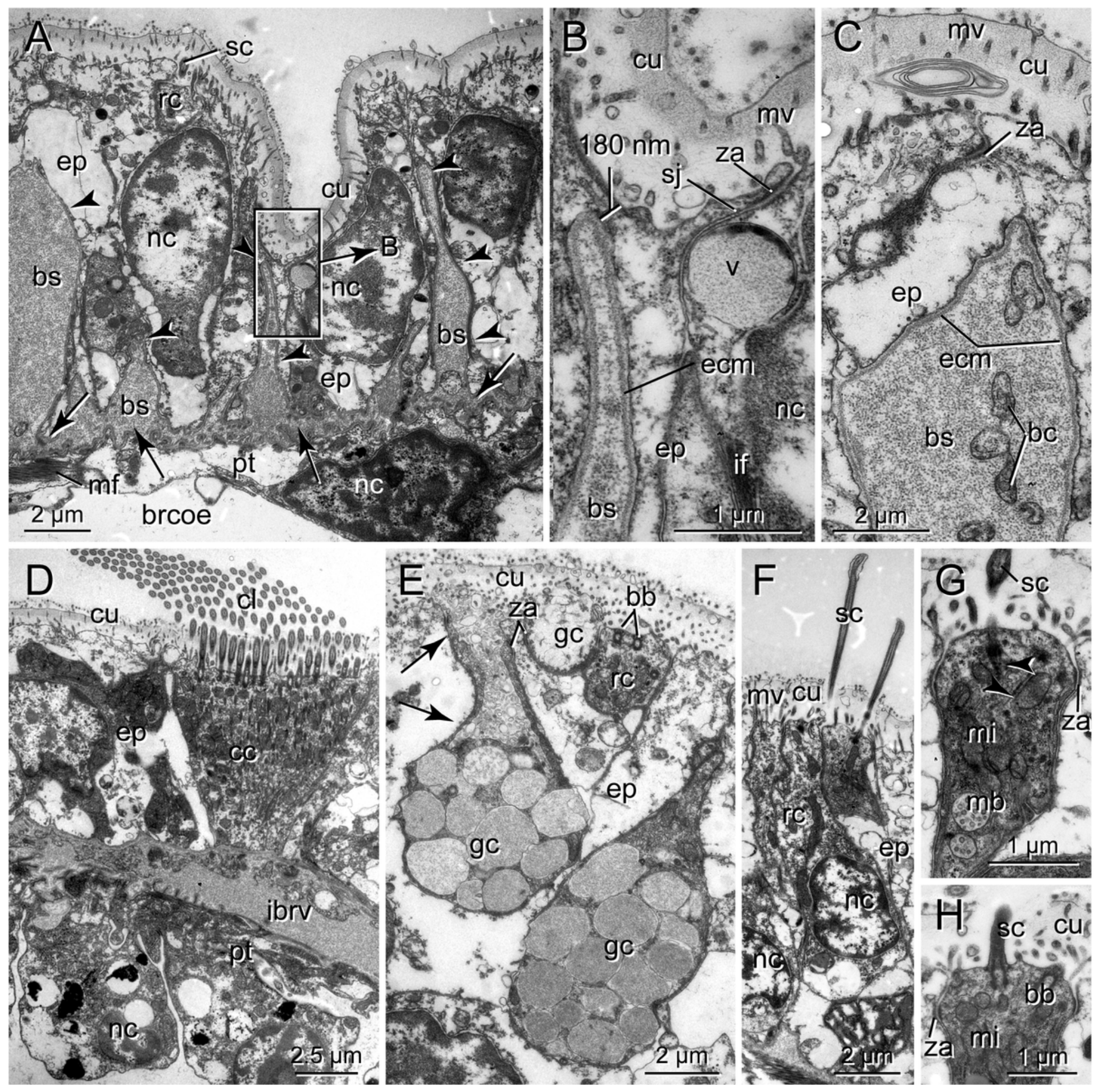

Figure 9

S. alveolata. Ultrastructure of branchiae, epidermis; TEM. a: Unciliated epithelium (ep) above branchial coelom (brcoe), basal blood space (bs) gives off several branches (arrowheads) extending towards the surface; note receptor cell process ( $\mathrm{rc}$ ) with sensory cilium (sc). b: Enlargement of boxed area in a to show minimal distance between blood space and cuticle (arrow), blood space bordered by ECM (ecm). c: Blood space (bs) between epidermal cells (ep), cuticle (cu) without collagen fibers traversed by a few microvilli (mv; extensions of hemocyte (bc) reach into blood space. d: Densely ciliated cell (cc) belonging 
to curved ciliated band between epidermal supportive cells (ep), cells situated above inner branchial vessel (ibrv); coelomic site of vessel bordered by granulocyte-like peritoneal cells (pt). e: Gland cell necks (gc) and multiciliated receptor cell process (rc) embedded between epidermal supportive cells (ep); arrows point to deeply invaginated aperture of type-2 gland cell. f: Group of three receptor cells, cut in different planes, two of which (on the left) uniciliated and with cell body and nucleus (nc). g: Dendritic process with diminutive rootlets of sensory cilia (arrowheads). h: Sensory cilia (sc) and basal bodies (bb) of dendritic process. bb basal body, bc blood cell (haemocyte), brcoe branchial coelom, bs blood space, cc ciliated cell, cl cilium, cu cuticle, ecm extracellular matrix, ep epidermis, gc gland cell, if intermediate filaments, ibrv inner branchial vessel, mb multivesicular body, mf myofilaments, mi mitochondrion, $\mathrm{mv}$ microvillus, nc nucleus, pt peritoneum, rc receptor cell, sc sensory cilium, sj septate junction, v vesicle, za zonula adherens. 

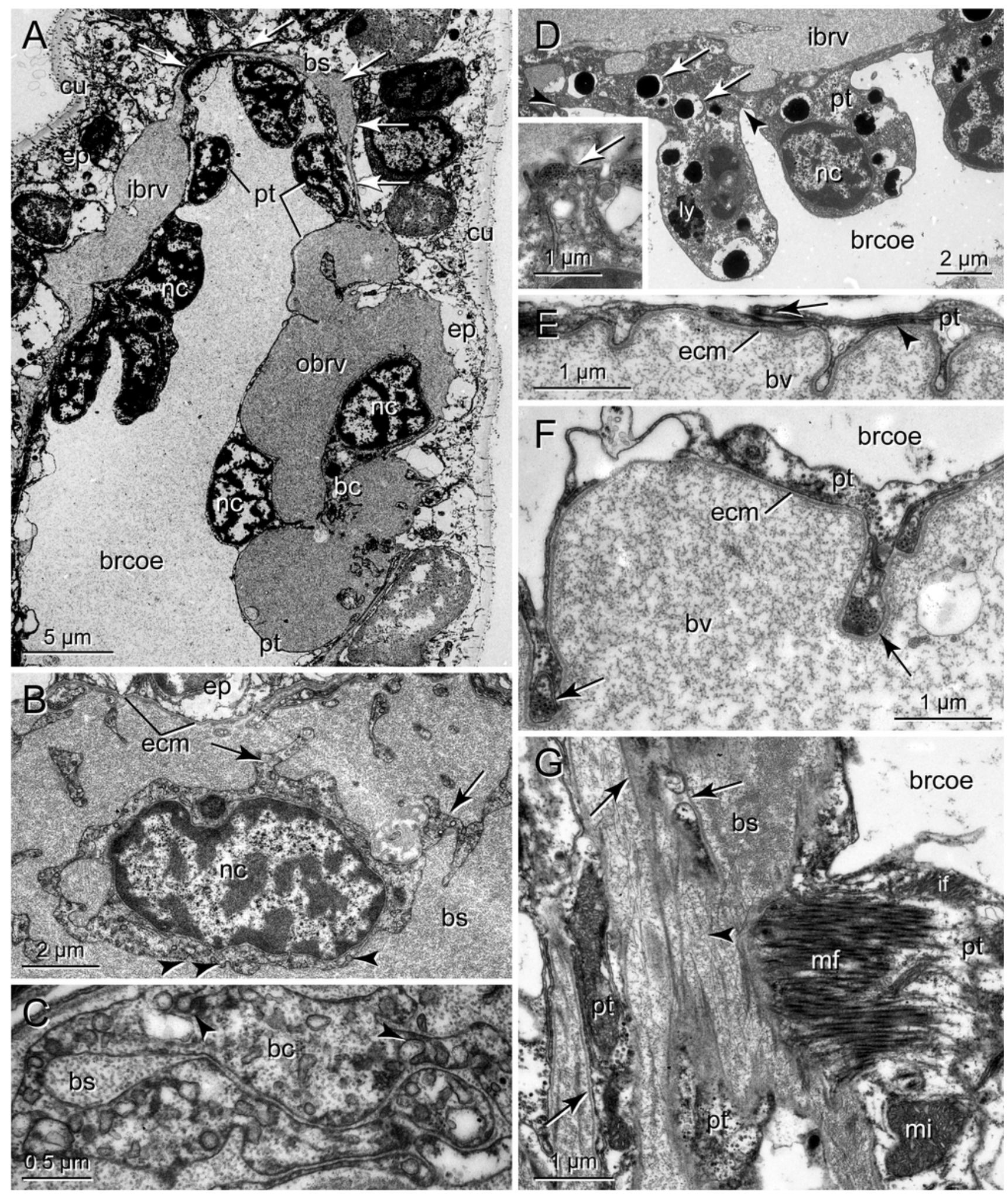

Figure 10

S. alveolata. Ultrastructure of branchiae, coelom and blood vessels; TEM. a: Somewhat oblique section through middle region of branchia showing inner and outer branchial vessel (ibrv, obrv) and a connecting blood space (bs, arrows); note blood cell (hemocyte [bc] in obrv; the peritoneum (pt) is formed by cells of varying thickness reaching their maximum thickness around the nuclei (nc). b: Blood cell with nucleus (nc) and branched sheet-like extensions (arrows), arrowheads point to coated pits. c: Enlargement of 
hemocyte process with numerous endosomes, coated vesicles and a few coated pits (arrowheads). d: Coelomic lining (pt) of the inner branchial vessel (ibrv) formed by granulocyte-like cells with numerous electron-dense granules and lysosomes (ly); Inset shows basal part of granulocyte-like cell facing to blood vessel with bundle of myofilaments (arrow). e: ECM (ecm) forming wall of blood vessel (bv) covered by extremely thin coelomic lining (pt), arrow points to zonula adherens, arrowhead to septate junction between adjacent peritoneal cells. f: Coelomic lining covering blood vessel (bv) composed of myofilament-free and myofilament-containing cells (arrows). g: Tangential section through several basal regions of blood spaces (bs) and branchial coelom (brcoe); peritoneal cell with myofilaments (mf) and intermediate filaments (if); peritoneal cells followed by ECM (arrows) and blood space (bs); between blood and ecm a loose meshwork of collagen-like fibers is present (arrowhead). bc blood cell (hemocyte), brcoe branchial coelom, bs blood space, bv blood vessel, cu cuticle, ecm extracellular matrix, ep epidermis, ibrv inner branchial vessel, if intermediate filaments, ly lysosome, mf myofilaments, mi mitochondrion, nc nucleus, pt peritoneum.

\section{Supplementary Files}

This is a list of supplementary files associated with this preprint. Click to download.

- SupplementaryVideoSabellariaBranchiae3DModel.avi

- SupplementaryFigure02SabellariaBranchiaeTEMPoster.tif

- SupplementaryFigure01SabellariaBranchiae3DModel.tiff 